Med. Hist. (2020), vol.64(3), pp. 401-435. (c) The Author(s), 2020. Published by Cambridge University Press. This is an Open Access article, distributed under the terms of the Creative Commons Attribution-NonCommercialNoDerivatives licence (http://creativecommons.org/licenses/by-nc-nd/4.0/), which permits non-commercial re-use, distribution, and reproduction in any medium, provided the original work is unaltered and is properly cited. The written permission of Cambridge University Press must be obtained for commercial re-use or in order to create a derivative work.

doi: $10.1017 / \mathrm{mdh} .2020 .21$

\title{
The Amphibious Nature of AIDS Activism: Medical Professionals and Gay and Lesbian Communities in Norway, 1975-87
}

\author{
KETIL SLAGSTAD ${ }^{1,2} *$ \\ ${ }^{1}$ MD Institute of Health and Society, Faculty of Medicine, University of Oslo, \\ PO Box 1130 Blindern, 0318 OSLO, Norway \\ ${ }^{2}$ Institut für Geschichte der Medizin, Charité Universitätsmedizin Berlin
}

\begin{abstract}
This article is the first to explore Norwegian HIV/AIDS policy and activism. Drawing on a range of archival material and oral history interviews, it does this along two lines. First, it analyses how AIDS unfolded in the changing political landscape and health bureaucracy of the 1970s and 1980s. The question is addressed of how AIDS challenged and shaped social medicine, an important 'thought style' of the postwar health bureaucracy and an important factor in the creation of the welfare state. Second, the article contributes to a growing AIDS historiography tracing the genealogy of AIDS activism in gay and lesbian health activism in the preceding decades. At the advent of AIDS, formal and informal networks already existed between gay and lesbian communities, activist organisations and the authorities. The roles of gay and lesbian medical professionals and activists are traced, together with how they challenged paternalistic and heteronormative notions of social medicine and homophobic attitudes in the public healthcare system. By having one foot in the medico-political world and one in the queer communities, they were able to mediate and translate different kinds of expertise and knowledge to the authorities, the public and the affected communities. This 'amphibious' role gave them credibility with both the authorities and the communities when addressing public health issues and preventive work. However, this story demonstrates that gay AIDS activists were not immune to the reproduction of exclusionary or hierarchical mechanisms within the queer communities. It shows how
\end{abstract}

* Email address for correspondence: ketil.slagstad@medisin.uio.no

This article would not have been possible without all the people who decided to share their stories with me. Thank you all. Three anonymous reviewers were extraordinarily generous in providing thoughtful comments on the manuscript. A warm thanks to Thomas Rogers who helped me with my English and gave critical comments on various drafts. Anne Kveim Lie, Per Haave and Anne-Lise Middelthon provided valuable feedback. Thanks to the archivists at Skeivt arkiv, Oslo City Archives and the National Archives of Norway. 
the juggling of different roles sometimes posed difficult dilemmas for the activists and how challenging but important this amphibiousness was to them.

Keywords: Epidemics, Gay and lesbian health activism, Harm reduction, HIV/AIDS, Public health, Social medicine

\section{Introduction}

'Be there for your friends, don't let irrational fear take the upper hand and don't let anyone walk all over you because of AIDS!! Together we can break the steep increase!' ${ }^{1}$ This was the encouraging message in 1985 from a gay man, nurse and AIDS activist, directed at men who had sex with men to abstain from donating blood. The first cases of AIDS in Norway were reported in the early months of 1983 , and the news was widely communicated in the press, in the national medical journal and in the weekly reports of infectious diseases by the Norwegian Institute of Public Health. ${ }^{2}$ From the mid-1970s, activists and health professionals in the gay and lesbian communities had started to address the unmet health needs in their communities. When AIDS arrived, activists mobilised formal and informal networks between the gay and lesbian communities, activist organisations and authorities to hammer out a Norwegian AIDS policy. This article is the first to tell the story of early AIDS activism in Norway.

Historians have argued that scholarship on HIV/AIDS policy has tended to follow two strands of argument. ${ }^{3}$ One strand has analysed policy as part of conservative, liberalist agendas spurred by mass media hysteria and 'new moralism' (Thatcher, Reagan). ${ }^{4}$ The other strand argued that populist backlash had little effect on actual policy-making, which ended up being more shaped by medical 'professionalism' and activists. ${ }^{5}$ This strand included an attendance to the 'pre-history' of AIDS, contextualising AIDS responses in postwar policy debates and tensions. ${ }^{6}$ This article follows the latter approach along two lines.

First, it asks how AIDS unfolded in the changing Norwegian public healthcare system of the 1970s and 1980s. The creation of the welfare state and a public healthcare system

\footnotetext{
${ }^{1}$ Gay Health Committee by Calle Almedal, 'Blod', 23 September 1985, PA-1216 Det norske forbund av 1948, Db, box 3, Helseutvalget (hereafter 'Helseutvalget folder'), the National Archives of Norway, Oslo (hereafter NAN). 'Still opp for dine venner, ikke la urasjonell frykt ta overhånden og ikke la noen tråkke på deg på grunn av AIDS!! La oss sammen knekke den bratte kurven!'

2 ‘To innlagt på sykehus i Oslo, smittet av AIDS-sykdommen', Aftenposten 18 March 1983, 4; Miklos Degré, 'Ervervet immunsvikt - AIDS', Tidsskrift for Den Norske Lageforening 103, 11 (1983), 887-8; Arve Lystad, 'AIDS ervervet immunsvikt syndrom', MSIS-report no. 11, 1983, Statens institutt for folkehelse, Norwegian Institute of Public Health archive, Oslo (hereafter NIPHA).

${ }^{3}$ Janet Weston and Virginia Berridge, 'AIDS Inside and Out: HIV/AIDS and Penal Policy in Ireland and England $\&$ Wales in the 1980s and 1990', Social History of Medicine, 33, 1 (2018), 247-67.

${ }^{4}$ For conservatism, neoliberal ideology and the challenge to AIDS activism, see Jennifer Brier, Infectious Ideas: US Political Responses to the AIDS Crisis (Chapel Hill, NC: The University of North Carolina Press, 2009); Steven Epstein, Impure Science: AIDS, Activism, and the Politics of Knowledge (Berkeley, CA: University of California Press, 1996); Jeffrey Weeks, Sexuality and Its Discontents: Meanings, Myths and Modern Sexualities (London: Routledge, 1985), 44-57; Jeffrey Weeks, 'AIDS and the regulation of sexuality', in Virginia Berridge and Philip Strong (eds), AIDS and Contemporary History (Cambridge: Cambridge University Press, 2002), 1736.

${ }^{5}$ Virginia Berridge, AIDS in the UK: The Making of Policy, 1981-94 (Oxford: Oxford University Press, 1996), $5-6$.

${ }^{6}$ Berridge and Strong (eds), op. cit. (note 4).
} 
in the second half of the twentieth century was a political project with wide support across party lines. This included the creation of a centralised health bureaucracy where political and medical professional power became consolidated in the health director, who gained a unique position, directly under the minister, providing the director with broad authority to carve out public health policy and put it into action. Central to this project was a comprehensive concept of health and social medicine as a tool to enforce the welfarist programme - the dominant 'thought style' in the postwar health bureaucracy. ${ }^{7}$ In the 1970s and 1980s, the centralised structure had started to fall apart as the counties got increased control over public health policy, and in 1983, the directorate became a strictly professionalised administrative and advisory body. Hence, as the first cases of AIDS were reported in Norway, the health director, who had been the principal advocate for and implementer of public health policy rooted in social medicine, was dethroned from the powerful medico-political position and deprived of political power. How did AIDS play out in this new political landscape? In what ways did AIDS revive, mobilise, challenge and reshape the thought style of social medicine?

Second, the article seeks to position Norwegian AIDS activism within the gay and lesbian health activism preceding AIDS. Even though Norway was an egalitarian country, with strong popular support for the welfare state project, the 'Social Democratic Order' ${ }^{8}$ was nevertheless a paternalistic, heteronormative and fairly conformist state. The widespread stigmatisation and discrimination of queer people, especially in the healthcare system, led gay and lesbian healthcare workers and activists to establish health services for queer people in the 1970s. ${ }^{9}$ These services and activists would play an important role in confronting AIDS when it arrived some years later, and they played a crucial role in hammering out the Norwegian AIDS policy. By having one foot in the medico-political world and one in the queer communities, they were able to mediate and translate different kinds of expertise and knowledge to the authorities, the public and the affected communities. Gay and lesbian health professionals' 'membership' in the communities gave them credibility when addressing public health issues and preventive work. This unique position enabled them to create preventive health campaigns without being discredited as homophobic representatives of the official policy.

This article argues that it was exactly the 'amphibious nature' of their roles that would prove so crucial in the preventive work to come, as gay and lesbian healthcare professionals could freely 'move' between the different worlds - the medical, the governmental and that of the communities. ${ }^{10}$ This amphibious role gave them integrity and competence and enabled them to occupy a liminal space, characterised by what anthropologist Victor Turner in another context has defined as 'that which is neither this nor that, and yet is both'. ${ }^{11}$ Nevertheless, juggling different roles sometimes posed difficult dilemmas: to negotiate insecurities when little was known about disease mechanisms;

\footnotetext{
${ }^{7}$ Here, I refer to Ludwick Fleck's concept of 'thought style' [Denkstil], see Ludwik Fleck, Entstehung und Entwicklung einer wissenschaftlichen Tatsache (Frankfurt am Main: Suhrkamp, 1980 [1935]).

8 The concept was coined by Berge Furre in Vårt hundreår-Norsk historie 1905-90 (Oslo: Det norske samlaget, 1991) and popularised by Francis Sejersted, The Age of Social Democracy: Norway and Sweden in the Twentieth Century (Princeton: Princeton University Press, 2011).

${ }^{9}$ I use 'queer' to refer to people who identified as gay, lesbian or bisexual, and people who were attracted to and had sex with people of the same gender.

${ }^{10}$ I am indebted to Thomas R. Blair for this term, see Thomas R. Blair, 'Safe Sex in the 1970s: Community Practitioners on the Eve of AIDS', American Journal of Public Health, 107, 6 (2017), 872-9.

11 Victor Turner, The Forest of the Symbols: Aspects of Ndembu Rituals (Ithaca, NY: Cornell University Press, 1970), 99. I am indepted to Anne-Lise Middelthon for this reference.
} 
to seek cooperation with the state without being accused of co-optation, medicalisation and 'dilution of gayness'; and to avoid AIDS activism overshadowing gay and lesbian liberation work. Moreover, gay AIDS activists were not immune to the reproduction of exclusionary or hierarchical mechanisms within queer communities, and the perspectives of lesbian, bisexual and transgender people were often neglected. These dilemmas were not unique to Norwegian AIDS activists, as, for instance, scholarship on UK AIDS and drug activism has demonstrated. ${ }^{12}$ This article, however, seeks to analyse what was particular about the Norwegian example, how the amphibiousness and ambiguities were played out in a context of a fairly paternalistic welfare state and the landscape of a changing health bureaucracy imbued by the thought style of social medicine.

In her compelling study of venereal disease legislation in the three Scandinavian countries through the twentieth century, Ida Blom argued that the official Norwegian approach to the AIDS epidemic in many ways resembled Sweden's 'control-and-contain strategy'. ${ }^{13}$ In 1994, Norway removed its old law on venereal diseases, implementing a new one on contagious diseases, including HIV/AIDS, which included an option to use coercive measures in extreme and rare cases. Denmark, on the other hand, discarded its legislation on venereal diseases in 1988 and followed a 'cooperation-and-inclusion strategy'. ${ }^{14}$ In this article, based on archival material and a range of oral history interviews with activists, medical professionals and civil servants, I seek to complicate this view by, on the one hand, unpacking how the Norwegian AIDS policy unfolded against the public health thinking of social medicine and, on the other hand, how gay and lesbian activists challenged hegemonic policy, gained political power and mediated between communities and authorities.

In the vast AIDS historiography, ${ }^{15}$ the Norwegian situation has not received much, if any, attention from historians of medicine. ${ }^{16}$ This article seeks to contribute to a growing body of scholarship tracing the genealogy of AIDS activism in gay and lesbian health activism in the pre-AIDS era in various contexts around the world. Certainly, US AIDS activism was largely spurred by conservative politics and political ignorance, ${ }^{17}$

12 Alex Mold and Virginia Berridge, Voluntary Action and Illegal Drugs: Health and Society in Britain since the 1960s (London: Palgrave Macmillian, 2010), 101-20; Berridge, op. cit. (note 5).

${ }^{13}$ Ida Blom, Medicine, Morality, and Political Culture: Legislation on Venereal Disease in Five Northern European Countries, c. 1870-c. 1995 (Lund: Nordic Academic Press, 2012), 129. But as Blom also underlined, the use of force was contested among political parties, in the medical community, by HIV/AIDS organisations and by the Directorate of Health.

${ }^{14}$ For the Danish and Swedish history, see David L. Kirp and Ronald Bayer (eds), AIDS in the Industrialized Democracies: Passions, Politics, and Policies (New Brunswick, NJ: Rutgers University Press, 1992).

${ }^{15}$ Elizabeth Fee and Daniel M. Fox (eds), AIDS: The Burdens of History (Berkeley: University of California Press, 1988); Paula A. Treichler, How to Have Theory in an Epidemic: Cultural Chronicles of AIDS (Durham, NC: Duke University Press, 1999); Richard A. McKay, Patient Zero and the Making of the AIDS Epidemic (Chicago: University of Chicago Press, 2017); Brier, op. cit. (note 4); Berridge and Strong, op. cit. (note 4); Berridge, op. cit. (note 5); Carla Zelda Tsampiras, 'Poletics, Polemics, and Practice: A History of Narratives about, and Responses to, AIDS in South Africa, 1980-95' (PhD thesis: Rhodes University, 2012); Paul Sendziuk, 'Learning to Trust: A History of Australian Responses to AIDS' (PhD thesis: Monash University, 2001). The list is not meant to be exhaustive.

${ }^{16}$ But see Bjørn G. Iversen, 'Homosomatikk - Seksuelt overførbare infeksjoner og den norske hivhistorien i et homseperspektiv', in Marianne C. Brantsæter et al. (eds), Norsk homoforskning (Oslo: Universitetsforlaget, 2001); Olav André Manum, Kjarlighet, kunnskap og kondom - Den hivpolitiske kampen i Norge (Oslo: Pax, 2010); and the transcript of an oral history seminar, Stein Evensen et al. (eds), 'Da hiv kom til Norge', Michael 7, 1 (2010).

${ }^{17}$ Epstein, op. cit. (note 4); David France, How to Survive a Plague: The Story of How Activists and Scientists Tamed AIDS (London: Picador, 2016). 
nonetheless, this prism has obscured a more nuanced picture of interactions between health professionals and gay and lesbian communities. In the 1970s, community-based health services were created in US cities that were not merely directed at venereal diseases but which contributed to the formation of a broad concept of gay and lesbian health, including the negative health effects of stigmatisation, racism, homophobia and discrimination. ${ }^{18}$ Moreover, the concept of 'safer sex' originates from the pre-AIDS age in the late 1970s San Francisco, where a group of gay-friendly and sex-positive physicians started to address the increased problem of sexually transmitted infections and hepatitis B among gay men. ${ }^{19}$ From early in the US epidemic, activists and medical professionals, including mental health professionals, co-operated in unique ways to prevent, counsel and educate communities. ${ }^{20}$ In European countries, too, the queer communities played an early, fundamental role in the AIDS epidemic. In the UK, activist organisations like the Gay Medical Association and the Terrence Higgins Trust mobilised to provide health education, self-help and buddying services from the early 1980s. ${ }^{21}$ In West Berlin in 1983, a group of gay men and nurse Sabine Lange founded Deutsche AIDS-Hilfe, the national Germany AIDS organisation, by mobilising already existing networks in the gay communities. ${ }^{22}$ In the Netherlands, the fact that gay men were included in preventive work from the beginning ensured that their voices were heard and laid the groundwork for rapid responses to changes in the communities and subcultures. ${ }^{23}$

This article starts by mapping out the development of Norway's welfare system from the postwar era. In the rest of the article, I unpack Norwegian gay and lesbian health activism by first analysing the pre-AIDS era with the creation of the first public counselling service for homosexual men and women in Norway in second half of the 1970s. This would provide the groundwork for later AIDS activism. ${ }^{24}$ Then, I demonstrate how official Norwegian AIDS policy built on gay and lesbian health activism and, in particular, on the important role played by gay and lesbian healthcare workers. This history is exemplified by thorny topics that dominated the political and public discourse: blood donations among gay men; prevention strategies and information work; and mass testing for antibodies.

\section{The Welfare State, Social Medicine and the Directorate of Health}

The welfare state that grew out of the postwar era was a cross-party project. $^{25}$ In accordance with the Nordic welfare model, Norway sought to regulate capitalism with

\footnotetext{
${ }^{18}$ Katie Batza, Before AIDS: Gay Health Politics in the 1970s (Philadelphia: University of Pennsylvania Press, 2018). For the Australian situation and the importance of leaders of gay community organisations as intermediaries between health workers and the gay community, see Shirleene Robinson and Emily Wilson, 'Working Together? Medical Professionals, Gay Community Organisations and the Response to HIV/AIDS in Australia, 1983-85', Social History of Medicine, 25 (2012), 701-18.

19 Blair, op. cit. (note 10).

20 Thomas R. Blair, 'Plague Doctors in the HIV/AIDS Epidemic: Mental Health Professionals and the "San Francisco Model”, 1981-90', Bulletin of the History of Medicine, 90, 2 (2016), 279-311.

${ }^{21}$ Berridge, op. cit. (note 5), 13-23; Mold and Berridge, op. cit. (note 12), 101-6.

22 Michael Bochow, 'Political Activism and AIDS Activism Among Gay Men in Berlin' (paper presented at the Shaw, Centre for the History of Medicine, University of Warwick, 2009).

23 Theo Sandfort (ed.), The Dutch Response to HIV: Pragmatism and Consensus (London: UCL Press, 1998).

24 The scope of this article does not allow me to expand on the issue of IDUs or sex workers. For the history of sex workers and AIDS in Norway, see Ketil Slagstad and Anne Kveim Lie, 'Selling sex in the age of HIV/AIDS: activism, politics, and medicine in Norway, 1983-90', in Janet Weston and Hannah J. Elizabeth (eds), Alternative Histories of HIV/AIDS in Western Europe, 1980-2019 (Manchester University Press, forthcoming publication). 25 Sejersted, op. cit. (note 8).
} 
strong governmental control. ${ }^{26}$ The welfare state was made possible by the mobilisation of science including social sciences; the Nordic model was a positivist knowledge regime where empiricism, rationalism and quantification were transformed into and supported social-democratic policy. ${ }^{27}$ Medicine was a central tool in this process. National healthcare was a fundamental pillar of the expanding welfare state, supported by physicians in leadership positions who advocated the medico-political project of social medicine. The notion that the political system and societal structures were important to individual health and well-being came from early social-democratic medico-political thinking. ${ }^{28}$ The political became private and the private became political; the societal and individual body were inseparable - leitmotifs in the public health system created before and after the Second World War. But even if the Labour Party played a crucial role, the welfare state project enjoyed broad political support. The centre-right parties played a crucial role in securing a public healthcare system for everybody and broad social security rights for the population. For instance, in the six-year period from 1965 to 1971, when the country was governed by a centre-right coalition, a range of progressive reforms were implemented. Among these were the national public pension system (1966) and the Hospital Act (1969), which created a unified hospital system and made the counties responsible for building and managing the country's hospitals.

Following the end of the war, the Medical Directorate [Medisinaldirektoratet] and the Medical Department [Medisinalavdelingen] in the Ministry of Social Affairs were merged into one, the Directorate of Health. This gave the director direct access to the minister and turned the directorate into a unique political-professional creature in the Norwegian political system. Through preventive and curative healthcare, the state gradually took responsibility for more and more of peoples' lives in a system that strongly favoured certain trusted physicians' knowledge and competence. ${ }^{29}$ Karl Evang, the health director from 1938 to 1972, who had a degree in public health from Johns Hopkins University, arranged for the physicians he appointed to the directorate and for district medical officers [distriktslege] in the health councils across the country to have access to similar courses at the American university. With a strong central health administration dominated by physicians handpicked by Evang, district medical officers were given fairly free rein to use their medical knowledge and authority to pursue the goals of the welfare state by the means of social medicine. ${ }^{30}$ When Fredrik Mellbye became chief medical officer [stadsfysikus] of Oslo Health Council in 1972, he brought with him experience from the Directorate of Health, where he had been the head of the Office of Hygiene. There, he had been convinced of the importance of medicine for society and that modern social medicine with roots in public hygiene was an integral part of a welfare state. Prevention was central to these ambitions, and during the 1970s and 1980s the Council significantly expanded its reach by opening new public health departments, including, most importantly for this article, in 1985, a department for measures against AIDS, as well as a department for primary healthcare and a department providing relief measures to parents with children with disabilities. $^{31}$

\footnotetext{
${ }^{26}$ Rune Slagstad, De nasjonale strateger (Oslo: Pax forlag, 1998); Sejersted, op. cit. (note 8).

27 Slagstad, ibid., 367-69.

${ }^{28}$ Slagstad, ibid., 309-18; Aina Schiøtz, Folkets helse - landets styrke, 1850-2003, Det offentlige helsevesen i Norge 1603-2003, (Oslo: Universitetsforlaget, 2003), 199-203, 310-47.

${ }^{29}$ Schiøtz, ibid., 309-47; Trond Nordby, Karl Evang: en biografi (Oslo: Aschehoug, 1989), 156-58.

30 Schiøtz, ibid., 344-47.

${ }^{31}$ Fredrik Mellbye, 'Embetet som stadsfysikus i Oslo’, in Harald Siem, Kåre Berg and Berthold Grünfeld (eds),
} 
Because the public healthcare system was underpinned by the belief that problems and diseases should be addressed and solved by the means of societal solutions, sexual health, or sexology, was integrated into a broad definition of and approach to public health. In the article 'Sexual hygiene in bourgeois and socialist illumination', the young Evang, at that time a member of the communist organisation Mot Dag, attacked what he saw as a hypocritical bourgeois sexual morality rooted in Christian ethics full of denial and repressed needs, and argued that capitalism led to 'over-eroticisation' and the exploitation of peoples' desires, and that it prevented the healthy development of sexuality. Socialism, with work-life balance and gender equality, were seen as an antidote to this development. A reorganisation of society, he argued, would do away with patriarchal ethics and capitalism's exploitation of people's sexuality, and would lead the population to live emancipated, happy and uninhibited lives. ${ }^{32}$ Throughout his years as health director, Evang personally responded to hundreds, if not thousands, of letters from individuals who wrote about their sexual problems, including sexual guilt, erection failure and pain during intercourse. ${ }^{33}$ In a book about sexuality for lay people, in 1951, he wrote that a change was needed in 'the current moral views and in society's attitude' towards homosexuals to enable 'happy and worthy lives' ${ }^{34}$

At Oslo Health Council in the late 1970s, social medicine and sexology were unified in new ways. Here, the country's first medical position in sexology was established at Norway's first department of medical sexology. ${ }^{35}$ The department was an instrument for, on the one hand, incorporating the supervision of other health professionals into clinical work and, on the other, merging preventive and advisory work with public awareness work. Here, as we will see, an advisory service for gays and lesbians was established, and an expert group for people who wanted gender-affirming therapy was formalised. The department played an important role in raising public awareness and fostering sexual education in schools, and emphasised family planning, contraception and abortion services for young people. In Our Sexual Life, a book for lay people, Berthold Grünfeld, the department's first director, wrote that '[i]n our society, young people will usually find little or no help in this development of their sexual lives'. ${ }^{36}$ There was an inherent dilemma in modern capitalist societies: on the one hand, premarital sex was sanctioned, on the other, he argued, society, and especially the press, encouraged people to have sex and stimulated sexuality. Grünfeld thought this quandary called for nuanced and scientifically based medical public information. Medical technology and scientific progress were mobilised for the liberation of the population's sexuality: 'Increased openness, the access to factual information and not the least, modern and highly efficient prevention have helped eliminate much anxiety, insecurity, fear and uncertainty regarding one's sexuality. ${ }^{37}$

Samfunnsmedisin i praksis. Oslo Helseråd i 80-årene (Oslo: Universitetsforlaget, 1987), 22-7.

${ }^{32}$ Karl Evang, 'Seksualhygiene i borgerlig og socialistisk belysning', Populart Tidsskrift for Seksuell Oplysning, 1, 4 (1932), 199-224.

33 PA-0385 Karl Evang, O, Seksualkorrespondanse, NAN.

${ }^{34}$ Karl Evang, Seksuell opplysning - En popular framstilling av kjønnslivet og dets problemer (Oslo: Tiden norsk forlag, 1951), 371.

${ }^{35}$ Hans Døvik, 'Rådgivningstjenesten for homofile - egen seksjon for medisinsk sexologi', 3 July 1979, Oslo helseråd, box 122, Homofile, Oslo City Archives, Oslo (hereafter 'Homofile folder' OCA).

${ }^{36}$ Berthold Grünfeld, Vårt seksuelle liv (Oslo: Gyldendal, 1979), 62. 'Slik samfunnet er i dag, får unge mennesker som regel liten eller ingen hjelp i denne utviklingen av sitt seksualliv.'

${ }^{37}$ Berthold Grünfeld, 'Seksualitet som helseproblem', in Siem, Berg and Grünfeld (eds), op. cit. (note 31), 206. 'Den større åpenheten, tilgangen på saklig informasjon og ikke minst den moderne og høyeffektive prevensjonen har bidratt til å eliminere mye angst, usikkerhet, frykt og uro omkring egen seksualitet.' 
However, when Torbjørn Mork - like his predecessor, a physician - became the new health director in 1972, the strongly governmentalised, partly centralised system had started to fall apart. ${ }^{38}$ The Directorate of Health lost much of its power in 1983 as parties on both sides of the political spectrum had become increasing worried about its unique independent and powerful position. The year after, a new healthcare act terminated the role of the government-appointed district medical officer, and by the end of the 1980s the health councils had been dissolved. The tradition of government-employed district medical officers leading the health councils had roots dating back to the mid-nineteenth century. The councils and their medical officers had been a backbone of the public healthcare system and were crucial cogs in the wheel of social medicine. ${ }^{39}$ The reasons for this shift were manifold, but the official justification was democratisation and decentralisation. The protest movements of the late 1960s and 70s challenged a patriarchal, physician-dominated healthcare system, and a number of professionals and politicians wanted a seat at the table. ${ }^{40}$ Even if the administrative and professional axis joining district medical officers, county medical officers and the health director was disrupted, the new municipal medical officers [kommunelege] were still under municipal control. The result was not less but more public control of the health sector albeit on a decentralised level. ${ }^{41}$

Virginia Berridge has argued that UK AIDS policy should be seen in light of the changed landscape of public health in the postwar period, which, with the help of epidemiology, had 'redefined itself round a focus on the individual rather than the collective or the environmental basis of ill health' ${ }^{42}$ In the UK, public health thinking witnessed a 'decline' in the 1970s and 1980s with the reorganisation of the National Health Service and the termination of the public health role of medical officer of health. ${ }^{43}$ It is tempting to draw parallels to Norway, yet it would be misleading to characterise the structural changes taking place in the Norwegian healthcare system in the 1970s and 1980s as the result of 'neoliberal' ideology. The economic growth in the healthcare sector from the mid-1960s to the early 1980s was enormous. There was broad political support for getting as good health value as possible for the money spent, and, increasingly, cost efficiency became a political goal in itself, alongside equality, equity and social security. ${ }^{44}$ But public health thinking was still very much alive. For instance, in the first half of the 1980 s even the centre-right government defended a restrictive policy towards private hospitals to secure the dominant role of public hospitals. Generally, the Labour Party and the Conservative Party agreed about the broad outlines of health policy. ${ }^{45}$ In 1988, the government implemented the World Health Organization's 'Health for All by the Year 2000' strategy in a white paper,

\footnotetext{
${ }^{38}$ Nordby, op. cit. (note 29), 262-67. See also Ole Berg, Spesialisering og profesjonalisering. En beretning om den sivile norske helseforvaltnings utvikling fra 1809 til 2009 (Oslo: Statens helsetilsyn, 2009).

${ }^{39}$ Schiøtz, op. cit. (note 28), 349-86. For the history of the district medical officers, see Aina Schiøtz, Doktoren - Distriktslegens historie, 1900-84 (Oslo: Pax Forlag, 2003).

40 Schiøtz, Doktoren, ibid., 351-60.

${ }^{41}$ Per Haave, 'Velferdskommunen i støpeskjeen', in Anne Lise Ellingsæter et al., Den nye velferdsstatens historie. Ekspansjon og omdanning etter 1966, (Oslo: Gyldendal akademisk, 2020 [in press]); Schiøtz, op. cit. (note 28), 368.

${ }^{42}$ Berridge, op. cit. (note 5), 55.

${ }^{43}$ Virginia Berridge, Daphne Christie and Tilli Tansey (eds), Public Health in the 1980s and 1990s: Decline and Rise? (London: Wellcome Trust, 2006); Martin Gorsky, Karen Lock and Sue Hogarth, 'Public Health and English Local Government: Historical Perspectives on the Impact of "Returning Home", Journal of Public Health, 36, 4 (2014), 546-51.

${ }^{44}$ Per Haave, 'Sterkere politisk styring og begynnende markedsorientering i sykehussektoren', in Anne Lise Ellingsæter et al., op. cit (note 41).

45 Ibid.
} 
with the goal of securing fair distribution of limited resources, especially in an ageing population with increased demands for healthcare. The guiding concept was prevention, the major idea of social medicine, although with an increased focus on the individual and 'risk groups' ${ }^{46}$ Nonetheless, the explicit goal of the white paper was equity in health. ${ }^{47}$

\section{Health Professionals and Activism in the pre-AIDS Period}

In Norway, the prohibition of sex between men was removed from criminal law in 1972, even if there was no tradition of widespread prosecution of homosexual men. A decade later, homosexuality was removed from the list of psychiatric diagnoses by the Ministry of Social Affairs. The decriminalisation and depathologisation of male and female homosexuality were big victories for the gay and lesbian organisations. ${ }^{48}$ Nevertheless, negative attitudes towards gays and lesbians were widespread. At least among psychiatrists, homosexuality was often seen as pathological. For instance, in 1977, when the Norwegian Psychiatric Association, organised under the Norwegian Medical Association, recommended that its members avoid using the diagnosis 'homosexuality', the following press release underlined that it would refrain from discussing 'whether homosexuality should be regarded as a positive or negative way of life, since there obviously are differing views on homosexuality among psychiatrists'. ${ }^{49}$ The association "had not taken a stance on the question whether homosexuality is "as valuable" or "as normal" as heterosexuality'. ${ }^{50}$ Moreover, even if the director of the sexological department at Oslo Health Council defended the rights of gays and lesbians and argued against discrimination and criminalisation, he still defined homosexuality as a 'deviation' or 'anomaly' in his 1979 book for lay people about sexuality and sexual health. ${ }^{51}$ Kirsti Malterud, a lesbian, doctor and activist, recalled that misconceptions about homosexuality were prevalent in the medical community, including among psychiatrists practising 'conversion therapy' to treat what they saw as a mental illness. When she travelled to psychiatric hospitals to educate health professionals about sexuality and the specific health problems of sexual minorities, a recurring attitude among psychiatrists was that 'you can say whatever you like, but we know how we look at these people'. ${ }^{2}$ No wonder, then, that many homosexual people did not seek help, decided not to disclose their sexuality

\footnotetext{
46 St.meld. nr. 41 (1987-88), 20. ‘ . . f forebyggende arbeid som i større grad bør rettes mot risikogrupper'.

${ }^{47}$ Ibid., 22. For a comparison of public health strategies in the Nordic countries and specifically the role of social conditions versus individual responsibility, see Signild Vallgårda, 'Addressing Individual Behaviours and Living Conditions: Four Nordic Public Health Policies', Scandinavian Journal of Public Health, 39, 6 (2011).

48 DNF-48 (The Norwegian League of 1948), the first organisation for gay and lesbian liberation in Norway, was founded in 1950. The first organisation for lesbian women, Lesbisk bevegelse, was established in 1975. Arbeidsgrupper for homofil frigjфring (AHF), another queer organisation, was founded in 1976 as a result of disagreements within DNF-48 where people were excluded from the organisation. AHF organised more left-wing gay and lesbian activists and published the journal Lфvetann. Fellesrådet for homofile og lesbiske organisasjoner i Norge (FHO), established in 1979, included numerous organisations for queer people outside of DNF-48. In 1992, DNF-48 and FHO were unified in Landsforeningen for lesbisk og homofil frigjøring (LLH).

${ }^{49}$ Press release from the Norwegian Psychiatric Association, 'Psykiatrien og de homofile - en pressemelding', Nordisk Psykiatrisk Tidsskrift, 32, 1 (1978), 51-2. ‘ . . vurdering av homofili som en positiv eller negativ livsform fordi det selvsagt blant psykiatere er forskjellige oppfatninger av homofili'.

${ }^{50}$ Ibid., '. . vil presisere at man med denne uttalelse ikke har tatt stilling til om homoseksualitet er like "verdifullt" eller "like normalt" som heteroseksualitet'.

51 Grünfeld, op. cit. (note 36), 78.

52 Kirsti Malterud, 'Jubileum rådgivningstjenesten', notes, 28 November 1986, Oslo Helseråds rådgivningstjeneste for homofile, Rapporter og notater, 1978-80, Skeivt arkiv, Bergen (hereafter SA). 'Dere kan si hva der vil, men vi vet nå hva vi mener om disse. (Dikemark).'
} 
and even travelled across the country to Oslo to see a gay or lesbian doctor even for minor problems. $^{53}$

Hence, even if sexology and sexual liberation imbued the thought style of social medicine, in a paternalistic and heteronormative public healthcare system, homosexuality was still regarded as undesired and pathological. This was also the case in the public sphere. It was in this climate that, in 1975, a group of gay and lesbian health professionals, social workers, lawyers and theologians started an independent consultancy service for gays and lesbians in Oslo organised under the umbrella of gay and lesbian activist organisations. ${ }^{54}$ The activists quickly realised that a considerable need existed for more organised services, and one of them argued in a proposal to Oslo Health Council that even if society had become more open and liberal, 'prejudices created through generations' persisted in society. ${ }^{55}$ The professionals at the service saw patients who had met with prejudice or who had been rejected by doctors, and some patients had even been met with 'suggestions of sublimation' and attempts to be 'cured' either through psychoanalysis or hormonal therapy. Others were simply rejected by the doctors when they disclosed their sexuality. ${ }^{56}$ Many gays and lesbians were forced to live their social life in enclosed 'free spaces' like clubs, bars and restaurants. This lifestyle involved high intake of alcohol and a 'stressful night-life', which could worsen an already difficult personal situation. ${ }^{57}$ Gays and lesbians easily became a 'victim of self-condemnation', which could lead to problems that required help from a healthcare system in which 'the same attitudes as in the rest of society' flourished. ${ }^{58}$

As a result, a special counselling service for gays and lesbians, Rådgivningstjenesten for homofile, run by gay and lesbian health professionals, was established in September of 1977 as part of Oslo Health Council - Oslo's public health authority. The opening of a health service run by doctors, psychologists, nurses and trained social workers allowed queer people to discuss their medical concerns more openly without the risk of facing prejudice or rejection. After one year, the health professionals could draw the following conclusions about their patients: one in four were women; most people were between the age of twenty and thirty-five (even if people aged up to fifty sought help); they presented a mix of social, psychological and medical problems; and seventy-five per cent of them presented some kind of social or sexual problem or problems related to the acceptance of their sexuality. ${ }^{59}$

53 Georg Petersen, 'Forslag om opprettelse av en rådgivningstjeneste for homofile ved Oslo Helseråd', 5 May 1977, Homofile folder, OCA.

54 The Counselling Service for Homosexuals, 'Rådgivningstjenesten: juridisk og sosial assistanse', L $\phi$ vetann, 1 (1977), 19, SA; Calle Almedal, Georg Petersen and Dag Thorkildsen, 'Erfaringer fra rådgivningstjenesten for homofile', undated, Homofile folder, OCA. The service was first organised under DNF-48, later under AHF. The first organisation for gay and lesbian doctors was founded in 1996.

55 Petersen, op. cit. (note 53).

56 Almedal, Petersen and Thorkildsen, op. cit. (note 54).

57 Petersen, op. cit. (note 53).

58 Petersen, op. cit. (note 53). Petersen referred to 'homofile' [homosexual], a term which nowadays usually refers to gay men. At that time, however, 'homofile' meant men and women, so when Rådgivningstjenesten for homofile [The Councelling Service for Homosexuals] was founded in 1977, the name signalled that it was a service for men and women. Kirsti Malterud, who worked there as a doctor, at that time referred to herself as a 'homofil kvinne' [homosexual woman], later, it felt more natural for her to refer to herself as a lesbian. Kirsti Malterud, phone interview with author, 27 May 2019.

${ }^{59}$ Calle Almedal, Kirsti Malterud, Åse Brit Johnsen and Georg Petersen, 'Foreløpig rapport fra Rådgivningstjenesten for homofile', 18 May 1978, Homofile folder, OCA; 'Årsrapport for Oslo helseråds rådgivningstjeneste for homofile, erfaringer og vurdering etter ett års prøveprosjekt, November 1977 til November 1978 ', 15-18, SA. 
Malterud, who worked at the counselling service from the beginning, recalled in an interview the important role the service played in educating other professionals and providing information in schools, prisons, hospitals and to the public. ${ }^{60}$ Lacking both professional experience and certified education in gay and lesbian health, combined with a lack of research and academic literature on professional counselling for homosexual patients, the health professionals brought with them their own experiences as gays and lesbians. ${ }^{61}$ No service of its kind existed in Norway or other Scandinavian countries at the time, and, to their awareness, no other public services directed at the gay and lesbian population existed in any European country, except in the Netherlands. Amsterdam's Schorerstichting, a government-supported mental health service for gays and lesbians founded in 1967, would play a central role in the Dutch AIDS response and become an important model organisation to which workers from the counselling service in Oslo travelled to learn. ${ }^{62}$

It soon became evident to people working in the counselling service that there was an unmet need for somatic healthcare services among gay men: hepatitis B infection, gastro-intestinal parasitic infections, and sexually transmitted diseases like gonorrhoea, chlamydia and condylomas had become a growing part of the epidemiological picture doctors saw in their patients. ${ }^{63}$ Even before AIDS, healthcare workers at the counselling service started to address specific somatic health problems in the gay and lesbian communities. ${ }^{64}$ This coincided with an increased focus on sexually transmitted diseases in the general population. Rates of gonorrhoea increased significantly in the population through the 1970s. Public health authorities ran big information campaigns including boards and TV commercials: 'You can have gonorrhoea without knowing it' and 'Tonight 36 Norwegians will get gonorrhoea. Use a condom' (Figure 1). ${ }^{65}$

In the 1970s, US health authorities had started to pay specific attention to health problems among homosexual men, particularly sexually transmitted diseases, for example with the national cohort studies of hepatitis B infection and clinical vaccine trials. ${ }^{66}$ In Oslo during the early 1980s, professionals from the counselling service travelled to queer bars to spread information and take blood samples, and the high hepatitis B infection rates among gay men confirmed findings from other large cities. ${ }^{67}$ This realisation led a group of healthcare workers to create a specific service in Oslo directed at the somatic health

${ }^{60}$ Kirsti Malterud interview with Siri Lindstad, 28 April 2016, SA and with author, op. cit. (note 58).

${ }^{61}$ In the annual report from 1977-78 the health professionals wrote that they had consulted much general literature on homosexuality but only one on the counselling of gay patients, Jack Babuscio's We Speak for Ourselves: Experiences in Homosexual Counseling (London: SPCK, 1976).

62 Frans van den Boom and Paul Schnabel, 'The impact of AIDS on the Dutch health care system', in Sandfort (ed.), op. cit. (note 23), 165-6, 171 note 2; Calle Almedal, 'Samanställning av svar från organisationer som arbetar med rådgivning till homosexuella', 17 April 1978, Homofile folder, OCA.

${ }^{63}$ Nowadays often referred to as sexually transmitted infections (STIs), historically often referred to as venereal diseases; Kirsti Malterud and Georg Petersern, 'Helseproblemer hos homofile', Tidsskrift for Den norske laegeforening, 25, 104 (1984), 1736-9.

64 Jan-Henrik Pederstad, interview with author, Oslo 17 June 2019.

65 Anne-Lise Middelthon and Svein-Erik Ekeid in Evensen et al., op. cit. (note 16), 25, 27; Arbeiderbladet 16 November 1978, front page, 11 and Dagbladet 28 June 1979, 9.

${ }^{66}$ Michelle Cochrane, When AIDS Began: San Francisco and the Making of an Epidemic (New York and London: Routledge 2004), 21-54; Richard A. Mckay, 'Before HIV: venereal disease among homosexually active men in England and North America', in Mark Jackson (ed.), The Routledge History of Disease (Routledge, 2016), 441-59; Batza, op. cit. (note 18).

${ }^{67}$ Petersen in Evensen et al., op. cit. (note 16), 20-1. 


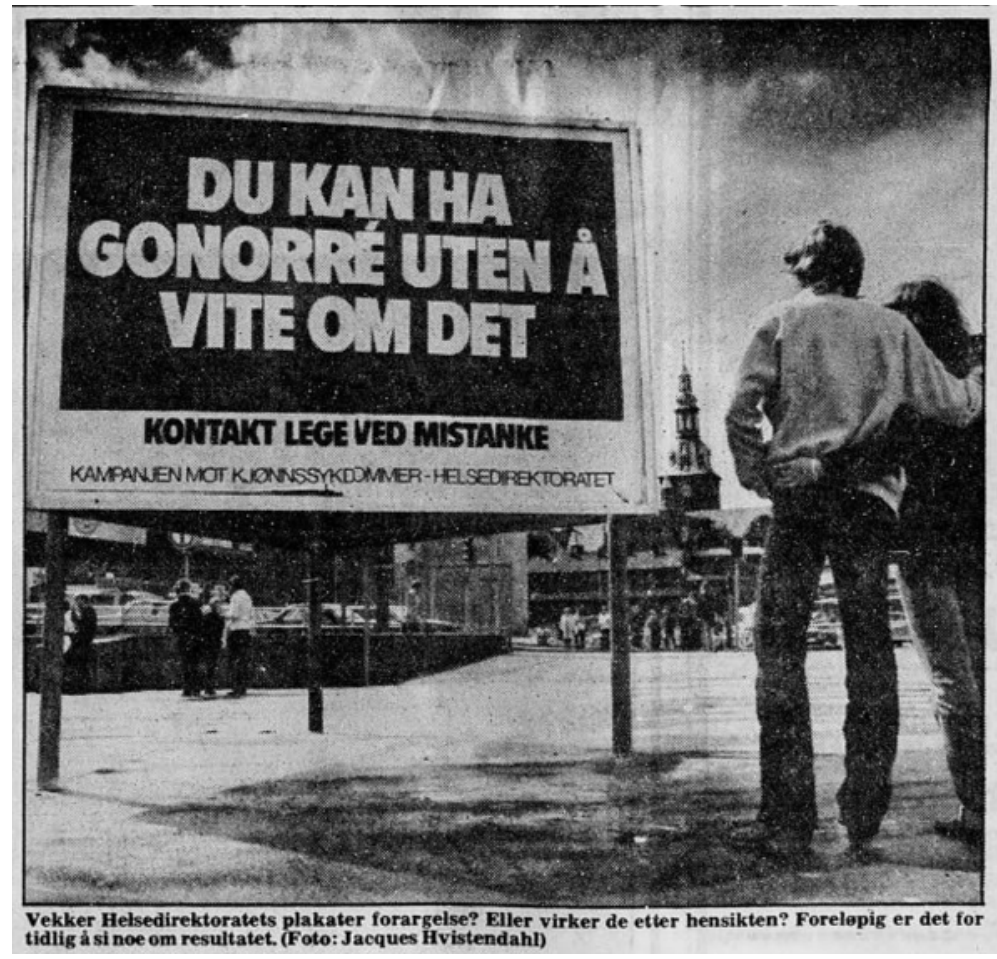

Figure 1: Facsimile from the newspaper Dagbladet 28 June 1979, of a high-profile public gonorrhoea campaign. The poster says: 'You can have gonorrhoea without knowing. Seek a doctor if you are concerned.' National Library of Norway, Oslo. Copyright: Dagbladet.

needs of gay men. ${ }^{68} \mathrm{~A}$ group of physicians wrote in a letter to the chief medical officer that many homosexual men were asymptomatic, but reluctant to get tested in the regular healthcare system for fear of being outed or of having to disclose their sexual orientation; sexually transmitted diseases would remain unrecognised if patients avoided informing their primary doctors about their sexuality and who they had sex with, the doctors argued. ${ }^{69}$ The gay and lesbian organisations DNF-48 and FHO also urged the health authorities to quickly establish a special health service for gay men, at the same time they underlined that they would reach out to gay men about getting somatic check-ups regularly and organise information meetings. ${ }^{70}$ These initiatives bore fruit. From September 1983, the Health Council offered somatic health check-ups, treatment for sexually transmitted diseases and vaccination against hepatitis $\mathrm{B}$, and the opening of the clinic was reported in the press. $^{71}$ The clinic would serve the population in the eastern and southern parts of Norway,

${ }^{68}$ Kari Wold Haug, Thor Gundersen and Georg Petersen to Stadsfysikus Fredrik Melbye, 'Forslag om helsekontroll for homofile menn', 19 April 1983, Oslo helseråd, box 52, Aids, OCA.

${ }^{69}$ Ibid.

70 Johan-Magnus Haakstad and Karen-Christine Friele to the health director and Oslo Health Council, 7 March 1983, Helseutvalget folder, NAN.

71 The counselling service for homosexuals by Georg Petersen, 'Helserådets tiltak mot AIDS og sykdom som er særlig hyppig blant homofile menn', 9 December 1984, Homofile folder, OCA; Tom Egeland, 'Homofilhelsekontor i Oslo', Aftenposten, 16 September 1983, 3. 
and the health director even approved the notion that, if needed, it could work as an outpatient clinic for the whole country. ${ }^{72}$ Gradually, experienced nurses and specialists in venereology and family care were recruited from other departments in the health council, and close cooperation with specialists in university clinics in the city was established. Two years later, in 1985, the service was turned into a special department for AIDS prevention, the first of its kind in the Nordic countries. ${ }^{73}$ Once again, the initiative came from the queer communities. Gay and lesbian health professionals would prove invaluable in the official responses to the AIDS epidemic, but it did not bring with it an increased attention to lesbian health. Quite the opposite, lesbian health was often neglected, even by the queer organisations. Gay and lesbian communities and queer organisations mobilised, but mostly unidirectionally, in solidarity with gay men.

\section{Crossing Communities: Different Kinds of Expertise}

Early AIDS activism among medical professionals in Norway grew out of the counselling service for gays and lesbians at Oslo Health Council. Georg Petersen, a general practitioner, public health officer in downtown Oslo and one of the founders of the counselling service, and later its director, played a key role in Norwegian AIDS prevention. Growing up in a working-class family, Petersen knew from a very young age that he was gay, and as a grown-up he appeared to people as 'a very confident homosexual' ${ }^{74}$ Friends and people who knew him well described him as a knowledgeable, serious and respected doctor who was loved for his cheerfulness, hospitality and empathy. ${ }^{75} \mathrm{He}$ had a clear goal of incorporating family medicine, sexology and social medicine to establish a system where people's health problems were not seen in isolation, but as part of their identities, communities and societies. He would play a crucial role in developing and promoting a broad concept of gay and lesbian health, including about the negative health effects of living in a heteronormative and homophobic society.

When the first cases of AIDS were diagnosed in Norway in 1983, this came as no surprise to healthcare workers. Before the first cases of AIDS were reported in the United States in 1981, Petersen had visited New York several times with his partner. 'We were familiar with the subculture', Petersen recalled. ${ }^{76}$ In the partly autobiographical novel, The Death of Desire? Confessions of a Man of the Gay Generation, his partner, Nils Johan Ringdal, described their experimental lifestyle:

From the second half of the 1970s, Georg Petersen and I systematically travelled to large cities and holiday destinations in the United States and Europe hunting for men and happy days. We visited New York and Berlin, Amsterdam and San Francisco, Mykonos and Ibiza, Key West and Fire Island, and we felt life racing as strongly as Augustin must have felt it in his time. ${ }^{77}$

In the summer of 1981, they moved to New York City, Ringdal as a visiting scholar at Columbia University, Petersen to do a masters in public health and to do research on

\footnotetext{
72 Torbjørn Mork to DNF-48, 'Om homofiles helseproblem', 9 August 1983, Helseutvalget folder, NAN; Gay Health Committee, minutes, 29 August 1983, Helseutvalget folder, NAN.

73 Fredrik Mellbye, Slit med helsa (Oslo: Gyldendal Norsk Forlag, 1989), 304.

74 Astri Lindholm, phone interview with author, Berlin/Oslo, 8 February 2019. Lindholm was a close colleague and friend of Petersen and worked as a psychologist supervisor at the counselling service.

${ }^{75}$ Lindholm interview, ibid.; Johannes Thorvaldsen, eulogy for Georg Petersen, Aftenposten, 5 April 2016.

${ }^{76}$ Quote by Petersen in Evensen et al., op. cit. (note 16), 22. '[V]i kjente subkulturen godt.'

${ }^{77}$ Nils Johan Ringdal, Lystens d $\phi d$ ? Bekjennelse fra en mann av gay-generasjonen (Oslo: Aschehoug, 1991), 14. In the foreword, Ringdal wrote that the book balanced between autobiography, travelogue and essay, and he thanked Petersen in the following way: 'In many ways, this book is as much his book as mine.'
} 
hepatitis B. From their apartment in Greenwich Village, in the epicentre of New York gay life, they witnessed and took part in a lifestyle and culture filled with sex, drugs and electronic music. Their stay, however, quickly became intertwined with the devastating epidemic. As a physician, student in public health and gay man, Petersen was confronted with the horrors of AIDS professionally and personally. Having witnessed members of his community die and friends perish, he returned to Oslo emboldened by the idea that an efficient response was contingent on engaging and working with the gay communities.

With him, Petersen had Calle Almedal, with whom he had co-founded the counselling service some years earlier. Before becoming a nurse, Almedal had studied theology and lived in a monastery, and explored gay metropolitan nightlife, including experimentation with drugs. Almedal had experienced gay sex culture first-hand: When he visited Petersen in New York City, he sold tickets in one of the biggest bathhouses, where he learned 'the importance of perfectly manicured nails when fist fucking'. ${ }^{78} \mathrm{He}$ also saw the consequences of what was then referred to as GRID (Gay Related Immune Deficiency), and he remembered in an interview that he became obsessed with what he could do as a healthcare worker to prevent a similar situation happening in Oslo. Given that 'so many Norwegians come here [to New York] and visit the bathhouses, it will happen here too', he remembered thinking. ${ }^{79}$ In the autumn of 1982, Petersen had just returned from his sabbatical. '[W]e became monomaniacally preoccupied by it, at least I did', Almedal recalled, saying he would call Petersen four-five times a day to discuss strategy in between the operations at the hospital where he worked. ${ }^{80}$

In New York, Petersen had visited the Gay Men's Health Crisis and several doctors who were engaged in preventive work and dedicated care for gay men and people with AIDS. Given their own experiences from gay communities, Almedal and Petersen became more and more convinced that gay men needed to change their lifestyle, but that this change had to come from within the communities, and that the message needed to be delivered by people who were themselves affected by the epidemic. In a letter to the gay and lesbian organisations, Almedal encouraged the organisations to leave former conflicts behind, as 'these disagreements are uninteresting as long as AIDS is a disease that efficiently kills those affected', and to establish a committee to handle the need for information about AIDS and sexually transmitted diseases among their members. ${ }^{81}$ Together with other gay and lesbian activists, Petersen and Almedal founded the first activist gay and health organisation 'because of the AIDS situation and the recognition that gay men in particular are at risk of sexually transmitted diseases and a will to do something with these conditions'. ${ }^{82}$ The Norwegian Gay Health Committee [Helseutvalget for homofile]

\footnotetext{
78 Calle Almedal, 'Og der satt jeg og grein', Hivnorge, 29 August 2013, webpage, https://hivinorge.wordpress. com/2013/08/29/og-der-satt-jeg-og-grein/ [downloaded 10 February 2019]. ' . . . nytten av å ha godt manikurerte negler ved Fist Fucking. Meget godt manikurerte!'

${ }^{79}$ Calle Almedal interview with Skeivt arkiv, May 2014. ‘ . . så mange nordmenn som reiser over og går på sauna her.'

${ }^{80}$ Ibid., 'Vi ble, jeg i hvert fall, monomant opptatt av det.'

${ }^{81}$ Calle Almedal to the gay and lesbian organisations in Norway, 28 April 1983, Helseutvalget folder, NAN. 'Disse motsetningene er dog uinteressante nettopp fordi AIDS er en sykdom som i meget høy grad dreper dem som rammes.'

${ }^{82}$ Gay Health Committee, 'Statutter for Helseutvalget for homofile', 12 December 1983, Helseutvalget folder, NAN. 'Helseutvalget er dannet på bakgrunn av AIDS-situasjonen og av erkjennelsen av at særlig homofile menn er utsatt for seksuelt overførbare sykdommer - og et ønske om å gjøre noe med disse tilstandene.'
} 
founded in $1983,{ }^{83}$ was modelled on the community-run Gay Men's Health Crisis and became the gay and lesbian organisations' coordinating body for AIDS information. ${ }^{84}$ Its statutes stated that the committee would consist of eight members, men and women, of whom at least two had to come from outside of Oslo. One member had to be appointed from the health director's working group on AIDS (see under), one from the counselling service at Oslo Health Council, three from DNF-48, two from FHO and one from the fetish organisation. It was later decided that all counties should be represented, and offices were founded across the country. Even if it was an explicit goal 'to work for a general improvement of the health situation of gay men and lesbian women', AIDS would come to dwarf the special health needs of lesbians..$^{85}$

There now existed two bodies from where AIDS activism emerged: the counselling service and the Gay Health Committee. But the gay and lesbian organisations mobilised too. In October 1983, DNF-48 put together a 'health plan for AIDS' to reach out to organised and unorganised gay men. To prevent stigma, all governmental recommendations had to rest on research-based knowledge and provide research to the gay and lesbian organisations and the public. DNF-48, meanwhile, would intensify the information work, but underlined that in every aspect of the prevention work, a close and formalised cooperation between activists, health services and the authorities should be sought. ${ }^{86}$ Important to this story is also the fact that gay health activists and professionals (of whom all were men) managed to get positions in governmental organs hammering out official AIDS policy. Yet it is unclear if the authorities themselves saw the importance of including activists or gay men, at least in the beginning.

In April 1983, the health director received two reports from an AIDS conference in New York: from Stig Frøland, an infectious-disease specialist, and Georg Petersen, who had communicated with AIDS researchers, doctors working with AIDS patients and activists. ${ }^{87}$ Both urged the director to establish an expert group to develop guidelines for diagnostics and therapy of AIDS and monitor and coordinate governmental preventive work. The director ended up transforming the former advisory board on vaccination into an advisory board on preventive infectious medicine [Rådgivende utvalg i forebyggende infeksjonsmedisin - RUFIM]. ${ }^{88}$ Under this board, a working group on AIDS was established, directed by a senior doctor at the Norwegian Institute of Public Health who appointed five other specialists in infectious diseases, immunology/transfusion medicine and microbiology - except Georg Petersen, who was appointed as a specialist in 'information technique and family medicine'. ${ }^{89}$ The health director now had a dedicated

83 'Gay' referred to men and women. It would later change name to Helseutvalget for homofile og lesbiske, i.e. the Health Committee for Gays and Lesbians.

${ }^{84}$ Petersen in Evensen et al., op. cit. (note 16), 22; the Gay Health Committee (Helseutvalget) continues to do important work in providing information and testing services for the LGBTQI population in Norway.

85 Gay Health Committee, op. cit. (note 82). 'Utvalget skal arbeide for å bedre helsesituasjonen for homofile og lesbiske generelt.'.

86 DNF-48, 'Helseplan for AIDS', 26 October 1983, Pa-1216 Det Norske Forbundet av 1948, Db, Box 7, Helsedirektoratet, NAN.

${ }^{87}$ Stig Frøland and Georg Petersen, reports from research trip to New York, 10 April 1983, S-1287 Sosialdepartementet, Helsedirektoratet, Hygienekontoret H5, 2, Dc, box 151, Aids (hereafter 'AIDS folder'), NAN.

${ }^{88}$ Torbjørn Mork to the Norwegian Institute of Public Health, 'Om arbeidsgruppe for ervervet immunsviksyndrom. Omdannelse av helsedirektørens rådgivende utvalg i vaksinasjonsspørsmål’, 8 June 1983, AIDS folder, NAN.

${ }^{89}$ Arve Lystad to Christian Lerche, 13 May 1983, AIDS folder, NAN; MSIS-report no. 35, 1983, Statens institutt for folkehelse, NIPHA. 
organ working on AIDS consisting of highly specialised medical professionals, of whom all were white men. Petersen was the only representative belonging to one of the perceived 'risk groups'; if he was appointed because of his sexuality and intimate knowledge about and access to the gay communities, that was not stated officially. However, there was no doubt that the director was aware that Petersen was gay. In a letter to DNF-48 about the new working group on AIDS, Mork mentioned only one name appointed to the group: Georg Petersen. ${ }^{90}$ This organ stayed in place until June 1985, when it was reorganised into the health director's advisory group on AIDS [Helsedirektørens rådgivningsgruppe for AIDS-sykdommen]. Of the twelve healthcare workers appointed to this group, ten were physicians, one nurse and one psychologist. Again, all were white, but this time two women were included. This group, however, had a more dynamic structure, and as new problems and perspectives emerged, new people were appointed, even 'representatives for HIV-positive people themselves'. ${ }^{91}$ Petersen was included this time, together with Calle Almedal. ${ }^{92}$ Finally, in 1987, when the minister of social affairs established a special group on AIDS [Sosialministerens referansegruppe i kampen mot HIV/AIDS-epidemien], they both sat at the table.

\section{Information Work 1: Negotiating Insecurities}

One of the earliest most urgent questions for AIDS activists was how to advise communities to prevent people from getting sick. In March 1983, at the time when Oslo Health Council distributed its first information leaflet about AIDS to gay men, the aetiological cause was unknown. The virus, which would be coined as HIV in 1986, was identified in a handful of studies between 1983 and 1984. When the first preventive suggestions were being made - even if the hypothesis of a new infectious agent gained more and more support in medical communities - several aetiological theories were circulating. The medical community was not univocal, and in gay communities the theories were manifold. As Richard A. McKay has shown, many gay men supported the hypothesis that AIDS was the result of several coinciding lifestyle factors, like drug use, partying, unhealthy lifestyles and recurrent sexually transmitted infections. ${ }^{93}$ The first leaflet about AIDS created by Almedal and Petersen demonstrates how difficult it was to provide sound advice when so little was known. In direct language they advised gay men to take responsibility for their own sexual lives: '[T]he more sex partners you have, the greater the risk of contracting AIDS'; 'You should reduce the number of partners, not have less sex'; 'Avoid anal sex with a random partner. Kiss a lot, but not in the ...'; 'Do not use back-rooms'; and 'Avoid poppers, and do not drink so much that you forget to give your name and address to the person you have sex with'. ${ }^{94}$ Although the advice left no room for doubt about the severity of the situation, it underlined that there was no reason for panic,

\footnotetext{
90 Torbjørn Mork to DNF-48, 'Om homofiles helseproblem', 9 August 1983, Helseutvalget folder, NAN.

${ }^{91}$ Ekeid in Evensen et al., op. cit. (note 16), 49.

92 The Directorate of Health, 'Helsedirektørens rådgivningsgruppe for AIDS-sykdommen', 15 July 1985, ALMA.

93 McKay, op. cit. (note 15), 289-353.

94 Georg Petersen and Calle Almedal, information leaflet, 'AIDS', 4 March 1983, AIDS folder, NAN. 'Desto flere sex-partnere du har, desto større risiko for å få AIDS og andre kjønnssykdommer. ... Du skal ikke ha mindre sex, men færre sex-partnere. ... Ha ikke anal-sex med en tilfeldig partner. Kyss gjerne og meget, men ikke i. . . Ikke benytt deg av back-rooms. ... Bruk ikke poppers, og drikk ikke så mye at du glemmer å oppgi navn og adresse til den du ligger med. ...'.
} 
and evoked the community spirit and importance of unity: 'These are simple suggestions we all can follow. ... We all have to do what we can to contain it [AIDS]. ${ }^{95}$

Importantly, however, the first information leaflet did not mention the use of condoms. As the debates in medical journals about condom safety showed, the role of condoms in preventing spread of the disease was contested, even several years into the epidemic. ${ }^{96}$ Information material from the mid-1980s underscored the importance of changes in lifestyle, like reducing the number of sex partners, avoiding anonymous sex ('always get the name and address of your partner') and traditional Norwegian public health suggestions such as 'have a proper diet, exercise and get fresh air' ${ }^{97}$ By 1985, however, condoms played an important role in the preventive suggestions. ${ }^{98}$ The queer journal Løvetann included small advertisements with statements like 'Gay and lesbian nurses encourage gay men: use condoms!' 99 In one information folder, it was stated that condoms are 'highly recommended for all those who think anal sex is an important part of sex life'. ${ }^{100}$ Activists in the Gay Health Committee deliberately tried to avoid one singular preventive strategy of condom-use. Kjell Erik Øie, a gay man, nurse and AIDS activist who would become the leader of DNF-48 and work for the Gay Health Committee, remembered that the Committee's preventive work instead suggested one of three approaches: sticking to one partner, celibacy or using condoms. ${ }^{101}$ Promoting condomuse was not unproblematic, especially for oral sex, even if the Gay Health Committee continued promoting the use of condoms for oral sex into the 1990s (Figure 2). ${ }^{102}$ The former leader of the Gay Health Committee recalled in an interview how activists constantly tried to balance the need to provide sound advice to the community while respecting the human need for sex and joy. ${ }^{103}$ For some couples, activists thought, it was possible to stay monogamous and not use condoms. ${ }^{104}$

Much less was known about the natural course of infection. In an information booklet for healthcare workers published by the Directorate of Health in 1985, it was assumed that, of people who seroconverted, only four to nineteen per cent would develop AIDS. In twenty-five per cent of those infected, it was thought, the virus would lead to pre-AIDS/lymphadenopathy-syndrome, e.g. suppression of the immune system without clinical significance. However, a large majority, sixty-five per cent, would remain asymptomatic, healthy carriers of the virus. ${ }^{105}$ In the first comprehensive information folder about AIDS for gay men, Petersen rebuked the idea that AIDS was a 'lifestyle disease', a gay man's disease: 'Coughing is not the cause of influenza', he wrote, 'we don't fight an influenza epidemic by prohibiting coughing, but by encouraging people

95 Ibid., 'Dette er enkle råd som vi alle kan følge. . . . Vi må alle gjøre hva vi kan for å begrense den [AIDS].'

96 See for instance Marcus Conant et al., 'Condoms Prevent Transmission of AIDS-Associated Retrovirus', JAMA, 255, 13 (1986), 1706.

${ }^{97}$ Gay Health Committee and Norwegian Red Cross, 'Hva er AIDS', folder, January 1985, PA-1216 Det norske forbund av 1948, Db, box 2, Narkotika, tannbehandling, kompendium, brosjyrer, NAN (hereafter 'DNF-48 Narkotika etc. folder'). '[S]ørg for å spise skikkelig, få mosjon og frisk luft'.

98 Ibid.

${ }^{99}$ Lфvetann, 1 (1985), 43. 'Homofile og lesbiske sykepleiere oppfordrer homser: Bruk kondom!'

100 Georg Petersen, Opplysningsbrosjyre om AIDS (Oslo: Helseutvalget for homofile, 1985), 54, DNF-48 Narkotika etc. folder, NAN.

${ }^{101}$ Kjell Erik Øie, interview with author, Oslo, 15 March 2019.

102 See for instance advertisement in Blikk, no. 9, September 1991, A-0078, Helseutvalget, Za, Avisutklipp, SA.

103 Eivind Åse, interview with Bjørn André Widvey, 7 May 2018, Skeivt arkiv.

104 Øie interview, op. cit. (note 101).

105 The Directorate of Health, Forholdsregler mot AIDS-sykdommen og mot HTLV-III/LAV-infeksjoner (Oslo: Helsedirektoratet, 1985), 3, DNF-48 Narkotika etc. folder, NAN. 


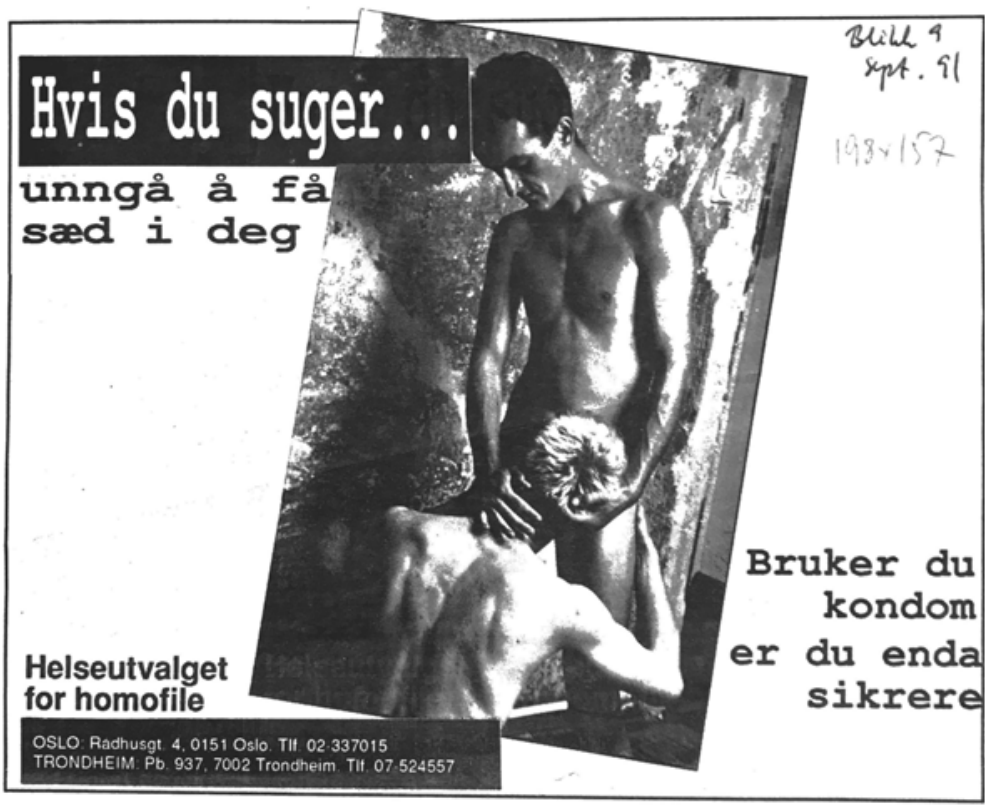

Figure 2: Safer sex ad from the Gay Health Committee, Blikk, 9 September 1991. The advertisement says: 'If you give blowjobs ... don't get semen in you. If you use a condom, you're even safer.' Skeivt arkiv, Bergen. Copyright: Helseutvalget.

not to cough directly at one another. ${ }^{106}$ The folder is a stark reminder of the fact that even if the HTLV-III virus was identified in studies in 1983 and 1984, it still was not clear in 1985 whether the virus was a sufficient factor in pathogenesis, or if other cofactors had to be present. ${ }^{107}$ The immunosuppressive role of other men's semen, poppers or Cytomegalovirus (CMV) infections could still not be completely ruled out, and the folder repeated the importance of good hygiene 'before and after sex', that one should stick to one partner and avoid anal sex or 'the transference of bodily fluids'. ${ }^{108}$ Even kissing was not without risk, it was thought, even if the risk was much less than for anal sex.

In society and the gay and lesbian communities there was a big need for information, and it did not take long for fairly inexperienced healthcare workers to become experts. But this dual role of being activist and healthcare worker - the very amphibiousness of AIDS activism - posed real problems in a time when little was known about disease mechanisms. Almedal recalled in an interview: 'One night we were allowed to use Metropol. I remember picking up Georg at the Health Council to have dinner before we were giving a talk and Georg was very nervous. ... "How do we do this", he said, and then said, "we do it like this: I handle the medical stuff and you talk about prevention"'. Almedal he continued

\footnotetext{
106 Petersen, op. cit. (note 100), 25. 'Hoste er ikke årsaken til influensa. Vi bekjemper ikke en influensaepidemi ved å forby hoste, men ved å oppfordre folk til ikke å hoste direkte på hverandre.'

107 See Epstein, op. cit. (note 5), 79-104 for the history of how the virus theory was consolidated. HTLVIII was the abbreviation of Human T-cell lymphotropic virus type III, and the virus was also referred to as Lymphadenopathy-associated virus (LAV), HTLV-III/LAV or AIDS-associated virus (AVS), before HIV became the norm in 1986.

${ }^{108}$ For the genealogy of the concept of 'bodily fluids' in North American history of AIDS, see Blair, op. cit. (note 10).
} 
laughing: 'Right, we have no idea what we are talking about, in 1983 we didn't know much, how are we supposed to talk about prevention then?'. ${ }^{109}$

\section{Blood Banks: How to Communicate a Message}

Early AIDS prevention work was mostly done by activists on a voluntary basis. In the early years of the epidemic, AIDS activists found little support in the authorities: 'Nobody wanted to listen to us. The Directorate of Health showed little interest and they didn't have any money', the leader of the Gay Health Committee said in an interview. ${ }^{110}$ One of the earliest public information meetings about AIDS organised by activists took place in the early months of 1983 at Metropol in Oslo, a restaurant and night-time venue for the queer community. Over 150 people attended what was described by some as the biggest meeting to ever take place there. Under the motto 'Responsibility for your own and other people's health!', Almedal and Petersen informed the primarily gay male audience about AIDS. One crucial message was that they should refrain from donating blood; importantly, people were encouraged not only to take care of their own health but to think about the community, protecting each other (Figure 3 ). ${ }^{111}$

It was not the first time that gay men had heard this message. In the autumn of the year before, a gay activist group called Gruppe Lambda had informed the gay community about the importance of abstaining from donating blood until more was known about the new disease, ${ }^{112}$ and FHO and DNF-48 encouraged gay men 'who had had especially numerous sex partners last year' to refrain from giving blood. ${ }^{113}$ According to DNF-48, for many people, including gay men, donating blood was a way of having their blood checked for diseases like hepatitis B without having to disclose to the doctor who they slept with or their sexual orientation.

At that time, the evidence of transmission by blood was inconclusive. In the first month of 1983, less than a dozen cases of AIDS had been reported in people who had received blood products in the United States. ${ }^{114}$ When Petersen reported back to the Norwegian officials three months later, from an international AIDS conference in New York City, he underlined what an expert had said, namely that 'none of the cases [of AIDS] could be related to blood transfusion with 100 per cent certainty'. ${ }^{115}$ A joint statement of the United States blood banks with other organisations underlined that the possibility of blood transmission should lead to additional precaution in the use of blood products and that

109 Almedal interview, op. cit. (note 79). 'Vi fikk låne Metorpol en kveld, og jeg hentet Georg på helserådet og så skulle vi spise middag før vi skulle ned til Metropol og snakke. Georg var utrolig nervøs. ... Og så sa han: Hvordan skal vi gjøre dette, hva skal vi si? Vi gjør det slik: Jeg tar det medisinske og så får du ta det forebyggende. [Ler] Nettopp ja, vi vet ikke hva det er vi snakker om, i 1983 visste vi ikke så mye, hvordan i huleste skal vi da kunne snakke om det forebyggende.'

${ }^{110}$ Eivind Åse in Hans Aarsund, 'Hva skjer i Helseutvalget?', Løvetann, 2 (1987), 22, SA. 'Ingen ville høre på oss i begynnelsen. Helsedirektoratet var lite interessert. De hadde jo heller ingen penger.'

111 'Ansvar for egen og andres helse. Sykepleier Calle Almedal og lege Georg Petersen informerer om kjønnssykdommer - med spesiell vekt på AIDS', Metropol-diskoteket, 14 March 1983, AIDS folder, NAN.

112 Georg Petersen, 'Homohets og homopest; AIDS-epidemiens konsekvenser for homoseksuelle menn', in Miklos Degré (ed.), AIDS i Norge (Oslo: Aschehoug, 1987), 108.

${ }^{113}$ Haakstad and Friele to Mork and Mellebye, op. cit. (note 70). ‘ . . våre medlemmer og andre som i løpet av de siste året har hatt uvanlig mange seksuelle kontakter med forskjellige partnere'.

114 Joint statement of Acquired Immune Deficiency Syndrome related to transfusion', American Association of Blood Banks, American Red Cross, and Council of Community Blood Centers, 13 January 1983, AIDS folder, NAN.

115 Georg Petersen to the health director, 'AIDS in homosexual men', report from trip to New York, 10 April 1983, AIDS folder, NAN. 


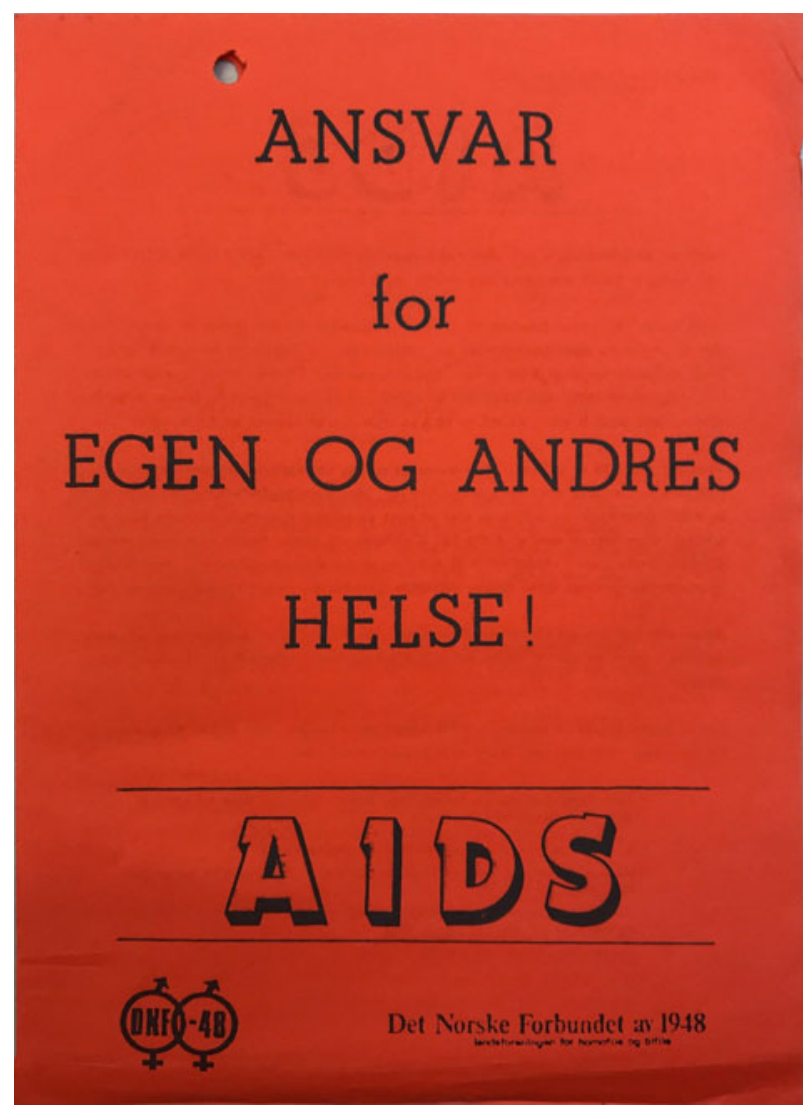

Figure 3: The likely first Norwegian information folder about AIDS, dated 4 March 1983, written by Georg Petersen and Calle Almedal and produced by DNF-48. The title page says: 'Responsibility for your own and other people's health!' Skeivt arkiv, Bergen. Copyright: Helseutvalget/Fri - foreningen for kjønns- og seksualitetsmangfold.

attempts should be made to limit blood donation from 'individuals or groups that may have an unacceptably high risk of AIDS'. ${ }^{116}$ One way to do this was to screen the donors for symptoms of AIDS, like night sweats, unexplained fevers and lymphadenopathy. Another was to prohibit gay men from donating blood. The blood banks' statement advised against this latter approach, however, because asking direct or indirect questions about a donor's sexual preference would be inappropriate: 'Such an invasion of privacy can be justified only if it demonstrates clear-cut benefit. ${ }^{, 17}$ Such an intervention might also prove inefficient, because there was 'reason to believe that such questions' were 'ineffective in eliminating those donors who may carry AIDS'. ${ }^{118}$ Blood banks, instead, were to cooperate with gay organisations to prevent donations by gay men.

During the spring of 1983, the health authorities took their first steps in creating a Norwegian prevention strategy. They believed that, instead of discriminating against

\footnotetext{
${ }^{116}$ American Association of Blood Banks et. al., op. cit. (note 114).

117 Ibid.

118 Ibid.
} 
vulnerable groups, such as gay men, when donating blood, the groups should be informed by community organisations about the disease and encouraged to abstain from donating blood until the aetiology and way of transmission was understood. ${ }^{119}$ In January 1983, on the initiative of its doctors, the main blood bank in Oslo made donors fill out a questionnaire that explicitly stated that gay men with many sex partners should refrain from giving blood. ${ }^{120}$ DNF-48 disapproved of this strategy, and ultimately the head of the blood bank was summoned to the health director's office and the hospital was made to change the questionnaire and its routines. The official guideline on blood donation, which was sent to Norwegian hospitals a month later, in April 1983, reproduced the Centers for Disease Control's so-called 'risk groups': sex partners of people with AIDS, sexually active gay and bisexual men with many sex partners, former and current users of injectable drugs, people with haemophilia and immigrants from Haiti. ${ }^{121}$ These groups - constructed on the basis of sexuality, nationality or disease, as opposed to practice - were teleported to Norway: ${ }^{122}$ ' $[\mathrm{B}]$ oth in theory and practice the same groups at risk of transmission are to be expected. ${ }^{123}$ A circular underscored that donors should get information about AIDS and who was at risk. Donors belonging to a risk group should not donate blood and had to sign an information letter. In hindsight, the health director's strong reaction towards the hospital that had implemented its own system while waiting for officials to act seems puzzling. The decision, however, mirrored the situation in the Netherlands, where blood banks initially wanted to exclude all gay men from donating blood, spurring the authorities to summon representatives from the blood banks, the haemophilia organisations and the gay and lesbian movement. They eventually ended up not excluding all gay men, but instead having gay and lesbian organisations tell members of the communities that gay men should abstain from donating blood. ${ }^{124}$

The debates around decriminalisation of sex between men and the recent removal of homosexuality as a psychiatric diagnosis might have been fresh in the minds of officials. Even if there was a long tradition of integrating a liberal philosophy towards sexual health in the policy of the Directorate of Health, being openly gay or lesbian was still highly stigmatised in society, also in the public healthcare system. Even if the questionnaire did not specifically ask the donors to specify whether they were gay or not, it could indirectly identify them if they abstained from donating blood after checking 'no' in all the other boxes for risk factors. The authorities probably included gay activists and gay organisations in the preventive work to create an official response that was sensitive to possible discriminatory effects of suggestions and interventions. The message was repeated in 1985, in a statement from the Gay Health Committee signed by Almedal,

\footnotetext{
119 The Office of Hygiene to the health director, 14 March 1983, AIDS folder, NAN.

${ }^{120}$ Magne K. Fagerhol, Har vi skjønt alvoret? (Oslo: Gyldendal, 1987), 11-23.

121 The Directorate of Health to Norwegian hospitals, 'AIDS', circular, rundskriv nr. 1-1030/83, Pa-1216 Det Norske Forbundet av 1948, Db, Box 7, Helsedirektoratet, NAN.

122 On the construction of 'risk groups', see Gerald M. Oppenheimer, 'In the eye of the storm: the epidemiological construction of AIDS', in Fee and Fox, op. cit. (note 15); Tsampiras, op. cit. (note 15), 30101; Mirko Grmek, History of AIDS: Emergence and Origin of a Modern Pandemic, Russel C. Maulitz and Jacalyn Duffin (trans.) (Princeton: Princeton University Press, 1990), 31-43. For the worldwide circulation of risk groups through AIDS maps, see Lukas Engelmann, Mapping AIDS: Visual Histories of an Enduring Epidemic (Cambridge: Cambridge University Press, 2018), 97-159.

123 The Directorate of Health, op. cit. (note 121). 'Overført til norske forhold vil man vel både i teori og praksis måtte regne med de tilsvarende grupper som smittefaregrupper'.

124 Onno de Zwart, Theo Sandfort and Marty van Kerkhof, 'No anal sex please: we're Dutch. A dilemma in HIV prevention directed at gay men', in Sandfort (ed.), op. cit. (note 23), 138-40.
} 
that 'men who have sex with men should not donate blood'. ${ }^{125}$ Ultimately, the way the message was delivered and by whom was as important as the content of the message itself.

\section{The Problems of Testing the Many}

Professional opinions differed about how to best contain the epidemic. One of the most controversial topics was whether people should be tested against their will. Again, the battleground was the blood banks. Even if some testing options had been available for use in hospitals since late 1984, the antibody tests, which became commercially available in Norway during the spring of 1985 , radically changed the epidemic in several ways. It now became possible to get completely new epidemiological overview of the epidemic, and the tests allowed members of risk groups to go from being per se targeted to actually having a definitive answer to whether they were infectious. They changed individual lives and their temporalities, present experiences and expectations for the future, in particular for a new group of people who were future ill but still not sick. The tests also provided new tools for the government to target preventive interventions.

In several countries, the tests spurred discussions about how far the government should go to test the population, if necessary, against their will. ${ }^{126}$ From an early point in the epidemic, directors of the Norwegian blood banks advocated testing all blood donors. Already around the turn of the year 1984, a medical microbiologist returned from the United States with an immunofluorescence test that showed that several Norwegian patients with haemophilia had developed antibodies against the virus. This was the first time that infection through blood donations was demonstrated in Norway. Doctors immediately contacted the health director to recommend the urgent implementation of screening of all blood donors. ${ }^{127}$ The director rejected the proposal, but directors of blood banks had secretly implemented routine screening of blood, and when the HTLV-III virus was detected in donor blood in the summer 1985, it caused outrage in Norwegian newspapers and led to much criticism of the reluctant official policy. ${ }^{128}$ The head of one blood bank called the health director's decision 'unbelievable!', sarcastically adding that it meant that 'in the meantime blood donors with AIDS should be able to donate as much

\footnotetext{
125 Gay Health Committee, 'Blod', op. cit. (note 1). According to Calle Almedal (interview, op. cit. (note 79)) and Georg Petersern (in Evensen et al., op. cit. (note 16), 65), the term 'men who have sex with men' [menn som har sex med men] was invented by a Norwegian anthropologist, Bjørge Andersen, working on a master thesis about cruising culture, Erotiske oaser $i$ offentlige sfarer: Amor obscurus: en studie av anonym homoseksuell adferd $i$ offentlige sfarer, (University of Oslo, 1987). From 1985, the term was increasingly in use in Norwegian AIDS information publications, and the first appearance in Norwegian newspapers appears to be in an interview with Calle Almedal in August 1985 (see Astrid Grynnlid, 'Starten på et helvete', Adresseavisen, 10 August 1985, 14). Almedal, who frequented AIDS conferences and meetings, might very well have been the one who popularised it. This nuances former claims that the term emerged in the US in the mid-1980s and was circulated by activists and researchers (see Tom Boelstorff, 'BUT DO NOT IDENTIFY AS GAY: A Proleptic Genealogy of the MSM Category', Cultural Anthropology, 26, 2 (2011), 287-312) or that it has been in use in research literature since the 1990s (see Rebecca M. Young and Ilan H. Meyer, "The Trouble With "MSM" and "WSW": Erasure of the Sexual-Minority Person in Public Health Discourse', American Journal of Public Health, 95, 7 (2005), 1144-9). ${ }^{126}$ Blom, op. cit. (note 13), 117-29; Signild Vallgårda, 'Problematizations and Path Dependency: HIV/AIDS Policies in Denmark and Sweden', Medical History, 51, 1 (2007), 99-112; Peter Baldwin, Disease and Democracy: The Industrialized World Faces AIDS (Berkeley: University of California Press, 2005); Sendziuk, op. cit. (note 15), 113-47.

127 Stein A. Evensen in Evensen et al., op. cit. (note 16).

${ }^{128}$ For the criticism, see Rikke Bjurstrøm, 'AIDS-alarm i blodbanken', VG, 13 August 1985, 6; Magne Fagerhol in Evensen et al., op. cit. (note 16).
} 
blood as they want'. ${ }^{129}$ How could the director's position be understood? Why was he reluctant to implement mass screening of blood?

There were, first of all, inherent problems with the tests and mass testing in general, including a risk of false positives. The directorate was wary because it was unclear whether the sensitivity and specificity was good enough and whether there was enough competence and equipment available to be able to conduct the tests. Second, and more importantly, the director asked whether there was a system in place to take care of those who tested positive: the healthcare system had to be able to 'follow, advice and take care of seropositive patients, and be able to handle psychosocial problems', the control programme for AIDS stated. ${ }^{130}$

Serological testing should not be started until the necessary systems were in place to take care of those whose test returned positive. The officials worried that implementing testing practice too early could have counterproductive effects: 'Experience has shown that testing without a system for follow-up can lead the clients to increase their destructive behaviour, intravenous drug use, prostitution $[\mathrm{sic}]$ or irresponsible sexual conduct. There also are examples of suicide and suicide attempts.' ${ }^{131}$ Testing the blood in the banks before testing services were available elsewhere could lead people to donate blood to get tested, and, as already mentioned, this was a widespread among gay men. That would pose a big threat to the donation system. In August 1985, the health director informed all county medical officers that screening of donor blood would be implemented and that they had to make sure that proper follow-up for people who tested positive would be provided. ${ }^{132}$

Two other issues underscore the divergent stances on prevention among doctors: the notion of coercive testing or testing behind people's back, and the idea of mass testing the population. Many physicians saw it as an undue interference in their professional decisionmaking to be told when to take a test or not, and argued that it should be a medical decision. ${ }^{133}$ The Directorate of Health, on the other hand, stated that all patients tested for HTVL-III had to be informed when they were tested, though this position was later moderated to some degree, so that testing as part of a medical examination did not require the patient's consent. ${ }^{134}$ Some doctors also advocated testing the whole population. 'Is it considered good "modern" epidemiology to risk the health of the population by trusting the risk groups', the head of a blood bank wrote in an open letter to the health director, demanding that the whole population be tested twice a year. ${ }^{135}$ In an opinion-editorial in a national newspaper, Georg Petersen repeated his belief in the voluntary philosophy. False positive results would 'create sleepless nights for many people and maybe also ruin

129 Quote by Gerd Selset in Bjurstrøm, ibid., 5.

130 The health director, 'Helsedirektørens kontrollprogram for AIDS-sykdommen', 2 July 1985, Helserådet, box 52 , aids, OCA. ' . . . være rustet til å følge opp, rådgi og dra omsorg for pasienter som viser seg å være seropositive, og som kan møte problemer av psyko-sosial art'.

131 The Directorate of Health, 'Helsedirektørens tiltaksplan for bekjempelse av HIV-infeksjonen', 15 October 1986, 35, NLN. 'En har erfaring for at testing uten at oppfølging er sikret, kan føre til at klientene øker sin destruktive atferd, sprøytemisbruk, prostitusjon [sic] og uforsvarlig seksualpraksis. Det er også eksempler på at det kan føre til selvmord og selvmordsfors $\varnothing \mathrm{k}$.'

132 The health director to Norway's county medical officers, 'Tiltak mot AIDS-sykdommen', AIDS-skriv nr. 5, 26 August 1985, NLN. For different reasons, nationwide screening of donor blood was not in place until March 1986. Fagerhol, op. cit. (note 123), 16.

133 Kåre Hunstad Jr, "“Hasard med menneskeliv", Dagbladet, 7 October 1986, 8.

134 The Directorate of Health, op. cit. (note 130).

135 Quote by Magne Fagerhol in 'Mork angripes for sin AIDS-politikk', Aftenposten, 25 July 1986, front page, '-Kan det virkelig være god, «moderne» epidemiologi å sette befolkningens helse på spill ved å sette sin lit til risikogruppene'; Hanna Hånes, 'Overlege: AIDS-test alle to ganger om året', Aftenposten, 26 July 1986, 25. 
a harmonious marriage'. He argued that those assumed to be most prone to infection, with whom the officials and the health services had established an efficient cooperation, would likely be scared away by the use of coercive measures. ${ }^{136}$ Former studies on screening had shown that around ten to twenty per cent of the population did not show up for testing. ${ }^{137}$

Living with AIDS was highly stigmatised on several levels of society. Very few people were publicly open about their illness, and officials perhaps had the discussions about testing that had been taking place in US gay organisations fresh in their minds. In the US, activists and gay organisations had advised gay men not to get tested. In 1984, the New York Native, a high-profile gay newspaper, recommended that gay men abstain from getting tested, since 'the meaning of the test remains completely unknown'. ${ }^{138}$ What was certain, the newspaper argued, was the "personal anxiety and socioeconomic oppression that [would] result from the existence of a record of a blood test result'. ${ }^{139}$ The test results could potentially have detrimental effects: 'Who will be able to keep this list out of the hands of insurance companies, employers, landlords, and the government itself?' ${ }^{140}$ A Gay Men's Health Crisis poster from 1985 stated 'The test can be almost as devastating as the disease' and went further in advising gay men to refrain from getting tested. ${ }^{141}$ In Norway, too, some people who tested positive lost their jobs. ${ }^{142}$ Insurance companies rejected applications for life insurance among HIV-positive people, ${ }^{143}$ and gay organisations and activists recommended gay men get insurance before taking the test. ${ }^{144}$ Many people argued that the test result would not change the lives of the people affected anyway: no cure was in sight and everybody had to live as if they were infected regardless. In the United States, AIDS organisations eventually landed on a consensus of anonymous testing. ${ }^{145}$ Norwegian authorities feared there would be a polarisation between gay and bisexual men and their organisations on one hand and the public health authorities on the other, as there had been in the United States. In a book for lay people, Georg Petersen encouraged gay and bisexual men to get tested, but for that to happen they 'must continue to trust the public healthcare system and politicians. But if the debate about coercive measures grows and more people lose their jobs and houses even here, we can expect the situation to become more polarised and politicised, and the fear of getting tested will increase'. ${ }^{146}$ The polarisation he feared was not just hypothetical.

\footnotetext{
136 Georg Petersen, 'Tvangstest tvilsomt våpen', Aftenposten, 31 July 1986, 2. 'Er det prisen verdt å frata så mange nattesøvnen og kanskje et harmonisk ekteskap'.

${ }^{137}$ Frøland in Evensen et al., op. cit. (note 16).

${ }^{138}$ New York Native, 8-21 October 1984, 5 quoted in Ronald Bayer, 'AIDS, ethics, and activism: institutional encounters in the epidemic's first decade', in Ruth Ellen Bulger, Elizabeth Meyer Bobby and Harvey V. Fineberg (eds), Society's Choices: Social and Ethical Decision Making in Biomedicine (Washington, DC: National Academies Press, 2013), 458-76.

139 Ibid.

140 Ibid.

141 GMHC poster, A-0078 Helseutvalget, Da, box 14, GMHC, SA.

142 The most famous case was Henki Hauge Karlsen, a server in a restaurant, who got fired because he was HIV-positive. He took his case to court and eventually won in the Supreme Court in 1988.

143 Elisabeth Lund, 'Ingen HIV-positive i Norge får tegne livs-forsikring', Helse- og sosialforum, A-0078 Helseutvalget, za, avisutklipp, SA.

144 Øie interview, op. cit. (note 101).

145 Epstein, op. cit. (note 5), 96 and note 60.

146 Petersen, op. cit. (note 112), 117. 'Dette forutsetter imidlertid at gruppen opprettholder tilliten til helsevesenet og politikerne. Men dersom debatten om tvangstiltak tiltar i styrke og omgang, og det blir flere som mister jobb og bolig også hos oss, er det all grunn til å forvente en sterkere polarisering og politisering, og en $\emptyset$ kende frykt for å la seg teste.'
} 
'We continue to receive messages about doctors in hospitals, outpatient clinics, and other health institutions who perform coercive HIV antibody testing of their patients', the Gay Health Committee wrote in a letter to gays and lesbians in October 1986, referring to testing being carried out behind the patients' backs or doctors' refusal to treat a patient unless he or she got tested. ${ }^{147}$ The activists recognised that healthcare workers could have a legitimate reason to be afraid of infection, but the testing practice was more often rooted in ignorance, since all blood and secretions from all patients had to be handled as potentially contagious and, more importantly, a negative test result did not mean that the person was not infected. Furthermore, they argued that some healthcare workers had a 'widespread distrust and suspicion towards the health authorities accusing them of being more concerned with protecting the risk groups than the risk of healthcare workers to get infected'. ${ }^{148}$ 'Norwegian doctors are about to destroy the test as an efficient tool in the fight against AIDS', they continued, 'which can undermine the confidence in the healthcare system among people in the risk groups.' ${ }^{149}$ Norwegian gay and lesbian organisations also encouraged people to get tested, while arguing that anonymous testing should be available. ${ }^{150}$ 'Coercive testing must not discredit the positive effects of HIV testing', they argued, underlining that the person's 'motivation for testing is the decisive factor!' 151

The health authorities argued the importance that if those who had increased risk of being infected were to get tested, they maintain trust in the healthcare system. ${ }^{152}$ Although a negative test result represented a golden opportunity to discuss safer sex and provide personal information, the antibody test was not to be seen as an efficient preventive measure in itself. The Directorate of Health argued that coercive testing was a brutal and dramatic measure, violated people's integrity and did not create the positive cooperative relationship needed between the patient and the physician. Furthermore, it maintained, it would mark a bad beginning for the 'intimate cooperation needed in information-outreach work and the continued process of preventing transmission'. ${ }^{153}$ Instead, the test needed to be branded as a 'positive health measure for the individual based on voluntarism and cooperation'. ${ }^{154}$ This chapter of Norwegian AIDS history in many ways resembles Australian policy, where communities were given big responsibilities for preventing transmission in lieu of coercive measures. ${ }^{155}$ In Norway, testing practice remained voluntary. Activists in the Gay Health Committee continued reaching out to county medical officers across the country to ensure that people who tested positive would be secured a 'psycho-social follow-up programme' including counselling and information

147 Gay Health Committee to its members, 2 October 1986, 'Advarsel om tvangstesting', Helseutvalget folder, NAN. 'Det kommer stadig rapporter om at leger på sykehus, poliklinikker, og andre helseinstitusjoner foretar tvangstesting av pasienter på HIV antistoffer (HIV = AIDS viruset).'

148 Ibid., 'Det eksisterer imidlertid også en utbredt mistillit og mistenksomhet til helsemyndighetene, som beskyldes for å være mer opptatt av å beskytte risikogruppene enn personalets muligheter til å bli smittet.'

149 Ibid., 'Norske leger er i ferd med å ødelegge testen som et effektivt virkemiddel i kampen mot AIDS'. 'Tilliten til helsevesenet hos personer i risikogruppene blir dermed undergravet'.

${ }^{150}$ Petersen, 'Homohets', op. cit. (note 112), 110-17; Gay Health Committee, 'Homofile og AIDS handlingsplan', May 1986, A-0078 Helseutvalget, Da, box 5, Brosjyrer, SA; Øie interview, op. cit. (note 101).

151 Gay Health Committee, op cit. (note 147). '[V]i må ikke la tvangstestingen diskreditere de positive sidene av HIV testen.' 'Det er hennes eller hans motivasjon for en prøvetaking som er avgjørende!'

152 The Directorate of Health, 'Forebygging og kontroll av HIV-infeksjoner', 1 March 1987, ALMA.

153 Ibid., '. . . vil derfor gi et dårlig utgangspunkt for det intime samarbeid som må finne sted i rådgivnings- og oppfølgingsprosessen for å hindre videre smitte'.

${ }^{154}$ Ibid., '. . . som et positivt helsetjenestetilbud til den enkelte basert på frivillighet og samarbeid'.

155 Sendziuk, op. cit. (note 15), 113-85. 
by medical personnel and support groups based in the gay and lesbian organisations. ${ }^{156}$ Importantly, even if the medical professionals and authorities argued that testing was based on consent and a voluntary approach, this was not the experience of everybody. 'When I got the HIV diagnosis by Georg [Petersen] early in 1985, my closest relatives and I were thrown into it', the gay activist Dag Strand Nielsen wrote in an article in 1994 titled 'When a doctor looks back', a stinging critique of Petersen's recollection of the history: 'Without consent, discussion, or counselling a frozen blood sample was tested for HIV. . . . Was this not an example of coercive testing? ${ }^{157}$

This period in history also illustrates the crucial role played by the Directorate of Health in hammering out policy and in responding to the AIDS crisis. The health director was much more visible in the public debate than his chief, the minister of social affairs. The health director became the conductor of the official political and medical response to AIDS, invoking the long tradition of social medicine and a paternalistic physician-led health bureaucracy. His style of leadership, powerful position and decision to follow a policy based on inclusion and cooperation was harshly criticised, by the former minister of justice among others. In an interview, she encouraged the minister of social affairs to 'call the Health Director Torbjørn Mork to account and demonstrate who is the head of the ministry'. ${ }^{158}$ This chapter of history demonstrates that, in a time of crisis, the long traditions and structures of public health were mobilised to respond.

\section{Information Work 2: The Many Faces and Banners of Activism}

In 1985 a shift took place in the governmental organisation of the AIDS work as the health director put together a small AIDS team working under his command, led by a physician. One member of the team recalled how they worked as an enclosed group with direct access to the director 'We had a lot of money. For instance, we had computers before everybody else in the directorate.' ${ }^{159}$ The directorate funded the Gay Health Committee, and the establishment of the AIDS team also led to a much closer cooperation between authorities and activists. '[I]n 1985, DNF-48, the Health Council and the Directorate of Health travelled together on a 10-day research trip to New York', the former leader of the Gay Health Committee recalled, and continued: 'We learned a lot about AIDS and about each other. This started everything in Norway. ${ }^{160}$ As activists continued to work in the communities, they also worked alongside government partners, at the same time as authorities explicitly sought a close cooperation with the affected communities and their organisations. This cooperation was often mediated by involved healthcare professionals. Norwegian AIDS work involved a myriad of formal and informal working groups and networks, and continuous personal contact between officials, gay and lesbian health

\footnotetext{
156 Gay Health Committee to county medical officers, 30 January 1986, Oslo helseråd, box 52, Aids, OCA.

157 Dag Strand Nielsen, 'Når en lege ser seg bakover', Lфvetann, 3 (1994), 47-48. 'Da jeg fikk diagnosen hivpositiv av Georg tidlig i 1985, ble jeg og mine nærmeste bokstavelig talt kasta ut i det. ... Uten samtykke, uten diskusjon, uten rådgivning ble en nedfrosset blodprøve av meg uten videre testet for hiv ... Var det ikke i praksis tvangstesting?'

158 Quote by Wenche Frogn Sellæg in Magnar Gjertsen, 'Vis Mork hvem som er sjefen', Adresseavisen, 12 January 1987, 4. '-Nå må sosialministeren ta et oppgjør med helsedirektør Torbjørn Mork og vise hvem som er sjef for departementet'.

159 Jo Kittelsen interview with author, Oslo 14 March 2019. 'Vi hadde masse penger, fikk PC før alle andre i Direktoratet.'

160 Åse interview, op. cit. (note 103). 'Men i 1985 dro DNF-48, Helserådet og Helsedirektoratet på en 10 dagers studietur til New York. Vi lærte mye om AIDS og om hverandre. Dette satte det hele i gang i Norge.'
} 
professionals and activists, and the communities themselves. ${ }^{161}$ The way people working in the AIDS team remembered it, it was 'completely uncontroversial' for the authorities to cooperate with the gay and lesbian organisations, especially since they were represented by gay and lesbian physicians and nurses. ${ }^{162}$ One person recalled how she would just pick up the phone and call the leader of the Gay Health Committee to make sure information and measures were suited for the affected communities they were developed for. ${ }^{163}$ For the AIDS team, it was crucial to 'follow the virus' to make sure that the measures would work. To make sure that the interventions would be efficient, they needed detailed information about how people actually had sex, and they required credibility and trust in the affected communities to succeed with their strategy.

Even if some gay healthcare workers ended up having official positions in preventive AIDS work, the initial initiatives started as grass-roots activism in different parts of the country. In Oslo, AIDS spurred activism among gay and lesbian general practitioners who more broadly wanted to protect their communities. ${ }^{164}$ In Trondheim, Norway's third biggest city, gay health workers also played a pivotal role in early non-governmental preventive AIDS work. There, in 1985, a gay activist and general practitioner, working with a gay nurse, started offering HIV testing on a voluntary basis. A year later the service was expanded into a public clinic with a psychologist and social worker, providing testing services, contact-tracing, hepatitis B vaccination and 'medical and psychological support' to asymptomatic HIV-positive people. ${ }^{165}$ In cooperation with the gay and lesbian organisations, they organised information meetings for the gay community and developed information material about safer sex. ${ }^{166}$ The gay and lesbian organisation in Bergen, Homofil bevegelse i Bergen, was led by two gay men and medical students. The leader recalled that this amphibious position gave them credibility 'both to use what we learned in medical school but also to influence the curriculum'. ${ }^{167}$ 'We engaged with the Department for infectious diseases in discussions and tried to cooperate with the departments for infectious diseases and dermatology and venereal diseases which did much of the HIV testing in Bergen.' ${ }^{168}$

Another example reflecting the increasing cooperation between the communities and officials was a large-scale 1986 information campaign. An information brochure developed by the Gay Health Committee used explicit language to give suggestions about safer sex for men who had sex with men. ${ }^{169}$ These included avoiding rimming and getting semen in one's mouth and being cautious if using sex toys with urine on them. The illustrations were humouristic, mirroring activist efforts in San Francisco. A big effort was made to

\footnotetext{
161 Øie interview, op. cit. (note 101); Anne-Lise Middelthon interview with author, Oslo 23 January 2019; and Kittelsen interview, op. cit. (note 159). Middelthon and Kittelsen were both part of the AIDS team in the Directorate of Health.

162 Kittelsen interview, op. cit. (note 159).

163 Anne-Lise Middelthon second interview with author, Oslo, 16 May 2019.

164 Pederstad interview, op. cit. (note 64).

165 Hans Blystad and Knut Skjærvold, 'HIV/AIDS in the Region of Trondheim, Norway', Trondheim kommune, September 1987, ALMA.

${ }^{166}$ Hans Blystad interview with author, Oslo, 18 March 2019. Blystad would later lead the public AIDS work in the Mid-Norway region.

${ }^{167}$ Bjørn G. Iversen interview with author, Oslo, 10 December 2019. ‘ . . både å bruke det vi lærte på studiet og å påvirke i studiet'.

168 Ibid. 'Vi engasjerte oss også med infeksjonsmedisinsk avdeling i diskusjoner og prøvde å være mye på lag både i infeksjonmedisin og hud og veneria som foretok mye av hivtesting i Bergen'.

169 Gay Health Committee, ' 10 helsevettregler for menn som har sex med menn', folder, A-0078 Helseutvalget, $\mathrm{Da}$, box 5 , Brosjyrer, SA.
} 
tailor the advice to the subcultures without doing harm. It was important to show that sex could be 'fun and good'. The Gay Health Committee had a range of tools in its prevention kit: safer sex seminars for gay men in hotels with paid lodging (where participants were told to jerk off with a condom and talk about it after), safer sex workshops with overhead instructions of where to ejaculate safely and group meetings whose assigned homework was to jerk off in a condom to learn how condoms worked and felt. ${ }^{170}$ They also established an anonymous information hotline and automatic answering machine with information about safer sex (the Norwegian Red Cross had Wenche Foss, one of Norway's most famous stage actresses at the time, record a message about safer sex that explained, for instance, that AIDS was not contracted through sharing toilet seats). ${ }^{171}$ A lesbian activist working in the Gay Health Committee recalled that, in the late 1980s, activists increasingly started working on outreach prevention work at grass-roots level in bars, clubs and saunas in the Stop AIDS project. ${ }^{172}$ 'It was a different way of working ... We had the Virus group create a show for gays and organisations across the country, financed by the Committee. They were dressed up as stewardesses, and you know before take-off they demonstrate security measures etc. so they demonstrated how to practise safer sex.' ${ }^{173}$

The strategy laid out by the activists would later be referred to as harm reduction and would be a philosophical foundation for the official Norwegian AIDS strategy: priority was given to the individual and his or her situation in relation to others, the communities and society. Instead of giving totalising advice or demands, a preventive programme was to be developed that would speak to people with different needs and desires, so that everybody could be empowered and learn something to protect their bodies and health. This was a new way of thinking about public health and of putting social medicine into action. Even though social medicine and sexual health had been a leitmotif of the health director, in many ways, the postwar healthcare system and public health thinking were paternalistic and directed from the top down. AIDS changed this, as the government was forced to work with communities, making the authorities rethink preventive health. This new approach shared some resemblances with more general changes in public health thinking in the UK, where the 'health promotion paradigm' in the 1980s and 1990s 'began to challenge the dominant public health approach characterised by a patronising and patriarchal medical establishment' ${ }^{174}$ In the Norwegian AIDS policy, harm reduction and grass-roots activism represented a new approach to social medicine in action. It involved a lot of experimenting and learning along the way, but with the objective of empowering and involving target groups.

Prevention work had to be creative and playful while underlining the need to change sexual habits. To refrain from everything fun and pleasurable would only cause stress, which could then weaken the immune system. The biggest challenge to gay men in the 1980s was the fact that 'we have to use our fantasy to develop sides of ourselves which we have neglected, and maybe refine the parts of our sex life which are not particularly risky'. ${ }^{175}$ '[W]e have to learn to limit our actions', a gay activist and nurse working at

\footnotetext{
170 Øie interview, op. cit. (note 101).

171 Almedal interview, op. cit. (note 79).

172 Turid Eikvam interview with author, Oslo, 18 December 2019.

$173 \mathrm{Ibid}$. 'Det var en annen måte å jobbe på. . . . Virusgruppa fikk vi til å lage show som de kunne reise rundt til homsene og organisasjonene i hele landet. ... De var utkledd som flyvertinner, du vet på starten av en flyreise skal man presentere sånn og sånn, og sikkerhet og sånn, .. . presentasjon av helsevettreglene og sånn'.

174 Jeff French in Berridge, Christie and Tansey, op. cit. (note 43), 36.

175 Petersen, op. cit. (note 100), 55.
} 
the counselling service told a queer magazine, while emphasising that AIDS should not 'take away eroticism and joy of life from gay men'. ${ }^{176}$ People would only change their behaviour if they had positive role models. The success of preventive work hinged on building self-esteem and 'creating a positive image of our subculture'. ${ }^{177}$ The strategy was coined as three Ks: kjarlighet (love), kunnskap (knowledge) and kondom (condom). ${ }^{178}$

Nonetheless, it was not always easy for the gay health activists to balance a sex-positive and non-stigmatising message that respected the fundamental human need for sex and intimacy with their desire as health professionals to provide sound medical advice. A physician and activist remembered initially being sceptical: 'How do you go into the forest and talk about prevention behind a tree when people are there for cock? That was a big challenge, but I was wrong. ... I think there was something about showing respect, and they didn't distinguish between us and them, but showed that they also were part of it. ${ }^{179}$ Early on, the harm reduction approach met much resistance among gay men. One information folder for men who had sex with men encouraged people to 'save the long and wet deep kisses to the one you love the most!', as French kissing was thought to contract diseases. ${ }^{180}$ One activist remembered in an interview that 'this was a useless message. ... And we said that we cannot have it this way because it might be that the person you love the most actually was infected'. ${ }^{181}$ In early 1983 a physician present at a public meeting, where Petersen and Almedal informed the gay community about AIDS, said that a nurse should not 'come here and tell me how I should fuck', a comment which also points to the long tradition of arrogant positioning of doctors above nurses in medical hierarchies, giving primacy to doctors' knowledge and advice. ${ }^{182}$ Almedal recalled that another gay activist who was present at the gathering described the meeting as being punched in the stomach over and over again. ${ }^{183}$ According to Pedersen, there was 'a lot of resistance on the first meetings we had at Metropol'. ${ }^{184}$ Another activist described one of the meetings as 'a hell': 'People were furious and scared to death.' 185

Some gay doctors and activists endorsed a more explicitly sex-positive message, which resonated well in the community: '[I]t would be unrealistic to believe that our former

\footnotetext{
176 Per Kristian Svendsen in 'Hvordan takle AIDS-frykten?', Løvetann, 3 (1984), 31, SA. 'Men vi må lære oss å sette grenser for aktivitetene våre. ... ta livsmotet og gleden over homofil erotikk fra de homofile'.

177 Petersen, op. cit. (note 100), 55.

178 Hans Robertsen, 'Sterk video mot AIDS', Dagbladet, 24 June 1986, 17.

${ }^{179}$ Pederstad interview, op. cit. (note 64). 'Hvordan går du ut i skogen og snakker forebygging bak et tre når folk egentlig er ute etter kuk? Det er en stor utfordring, men langt på vei tok jeg feil. ... Det er noe med den respekten de viste, og at de ikke skilte mellom oss og dem, men at de var en del av det'.

180 Gay Health Committee, op. cit. (note 169). 'Spar de lange og våte tungekyssene til den du er mest glad i!'.

${ }^{181}$ Martin Blindheim interview with author, Oslo, 13 March 2019. 'Det var et håpløst budskap, selvfølgelig. Da ble det sagt veldig klart fra at sånt kan vi ikke ha. For det kunne være at den du var mest glad i faktisk var smittet'. 182 Almedal interview, op. cit. (note 79). Numerous sources confirm that one person in particular expressed his anger about the message about reducing the number of sex partners, however, the exact details about what he said differ. See Tom Ovlien, 'Aids i Norge: Homobevegelsen på offensiven i mer enn 10 år' in Jon Gunnar Arntzen (ed.), Med regnbuen som våpen: festskrift til Karen-Christine Friele (Oslo: Antinoos forlag, 1995), 65; Svein Skeid interview with Skeivt arkiv, Oslo April 2017. Skeid was an activist and member of the Oslo fetish community.

183 Almedal interview, op. cit. (note 79).

184 Georg Petersen in Evensen et al., op. cit. (note 16), 57. 'Riktignok møtte Calle Almedal og jeg ganske heftig motstand på de første møtene vi hadde på Metropol'. Metropol was a queer bar and nightclub in Oslo. The picture of initial resistance was confirmed in interviews with activists; Blindheim interview, op. cit. (note 181) and Øie interview, op. cit. (note 101).

${ }^{185}$ Kjell Erik Øie in Evensen et al., op. cit. (note 16), 59. 'Det var et helvete, folk var kjemperedde og sinte'.
} 


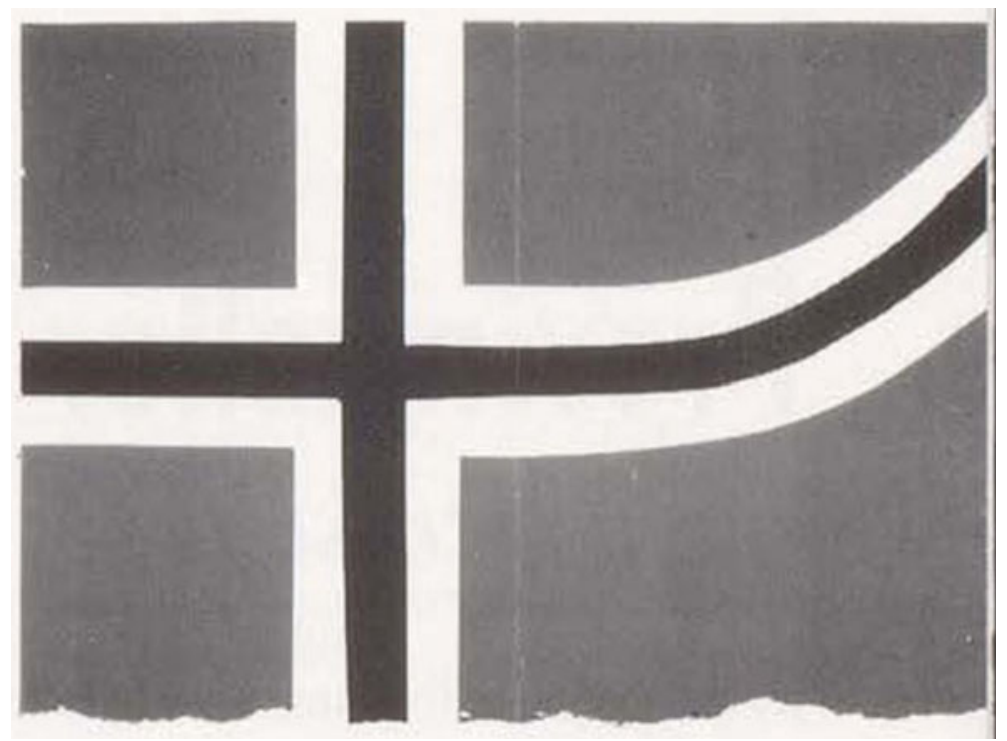

Figure 4: Poster of a sexually suggestive version of the Norwegian flag illustrating an article in Løvetann about sex-positive AIDS activism in Bergen. Skeivt arkiv, Bergen. Copyright: Løvetann/Skeivt arkiv.

strong needs for excitement no longer exist', a physician and activist wrote in $1987 .{ }^{186}$ 'We need to take these needs seriously and find ways of satisfying them in supportable ways.' ${ }^{187}$ Other activists were critical of gay and lesbian liberation having become too negative and focused on problems, and saw this as a result of Oslo's domination of activism: 'Oslo has been known as the gay metropolis ... Oslo's politics have been the politics of the country', the leader of the gay and lesbian activist organisation in Bergen wrote (Figure 4). ${ }^{188}$ 'Bergen is, at the moment, probably the main centre for the rethinking of queer politics and creativity', ${ }^{189}$ he continued about their efforts to break with negative thinking: 'We see it as a bigger threat to die from the lack of love than AIDS. And we say that in full responsibility. ${ }^{190}$

The discussions also point to the difficulties of combining the position as healthcare worker and activist: 'People were angry that we told people how they should live their lives. We were told that the main problem was that people had too little sex, not too much, because people were not open and could not express their sexuality. We shouldn't become the organisations that advocated monogamy. ${ }^{191}$

186 Jan-Henrik Pederstad, 'Sexologiske aspekter ved AIDS', in Gunnar G. Bolstad (ed.), AIDS - mobilisering til ansvar (Oslo: Forlaget LIV, 1987), 105. 'Men det vil være svært urealistisk å tro at våre tidligere sterke behov for spenning og opplevelse ikke lenger er aktuelle. Vi er nødt til å ta også disse behovene på alvor og finne måter å tilfredsstille dem på som er forsvarlige.'

187 Ibid.

188 Bjørn G. Iversen, 'Ja vi elsker!', Løvetann, 3 (1987), 18. 'Oslo har vært anerkjent som Norges homometropol ... Oslos politikk har vært landets politikk.'

189 Ibid., 18. 'Sannsynligvis ligger det største senter for homopolitisk nytenkning og kreativitet i dag i Bergen.'

${ }^{190}$ Ibid., 19. 'Vi ser det som en større trussel at vi skal dø av kjærlighet enn av aids. Og vi sier det $\mathrm{i}$ all ansvarlighet.'

191 Øie interview, op. cit. (note 101). 'Folk var sinte på at vi skulle legge oss bort i hvordan folk skulle leve. Folk hadde jo ikke for mye sex, folk hadde for lite sex. Det var hovedproblemet. Folk levde skjult og fikk ikke leve ut seksualiteten sin. Vi måtte ikke bli organisasjonene som snakket om monogami.' 
The close cooperation activists sought with the health authorities sometimes challenged their credibility in the communities: 'People told us that we were in the pocket of the health authorities, that we were bought and paid for, that we were given fancy computers and desks and were invited to expensive seminars.' ${ }^{192}$ As Virginia Berridge has demonstrated, some UK activists remained suspicious of working too closely with the state, as cooperation could imply co-option and incorporation with 'the compromises around gay identity which were thereby imposed' ${ }^{193}$ In Norway, too, the wearing of many hats posed difficult dilemmas for gay health activists. One AIDS activist and physician recalled how activists gathered in the apartment of Georg Petersen and his partner when AIDS came. Among other things, they talked about how to create efficient measures 'without killing the gay lifestyle but with respect for what gay men had been doing'. ${ }^{194}$ Nevertheless, it was important to the activists to demonstrate 'responsibility': 'Of course, it is not easy to establish more respect in society for cruising and Frogner Park and nightlife culture. There wasn't that much seriousness to point to.' ${ }^{195}$ Perhaps demonstrating 'respectability' became particularly important to activists in an egalitarian but heteronormative and fairly conformist society, the country of the Law of Jante? The story at least demonstrates how important and difficult it was for activists to balance between showing regard for their culture and communities on the one hand and demonstrating 'responsibility' to get support of the government and sympathy of society on the other. Furthermore, even if sexual health was an integrated part of the thought style of social medicine, it often tended to be heteronormative and not directed at the lives and health needs of queer people.

In many parts of society, the sex-positive message was not well received and even in medical circles it proved controversial. One information video developed by gay activists and healthcare workers provided concrete advice about how to have sex with condoms, how to practise safer BDSM sex (bondage/discipline, domination/submission, sadism/masochism) and advice for people living with AIDS of how to practise safer sex. The content, however, was shown in an unusually explicit way and included advice for safer fisting; when it was screened for doctors for the first time, several left the venue. ${ }^{196}$ Newspapers also rejected publishing safer sex posters developed by the Gay Health Committee (funded by the government) depicting shirtless men holding each other under titles like 'Pleasure and Care' and 'Safety and Responsibility' (Figure 5).

One of the editors in chief argued that he thought that 'this was supposed to be a campaign against AIDS not a promotion of homosexuality'. ${ }^{197}$ AIDS hit a society in which there was already a lot of unease about recent or ongoing cultural transformations: women's liberation, birth-control pills and sexual liberation were all fairly recent and contested developments in society. In many countries, including Norway, AIDS reinforced conservative opposition towards these changes, for instance in the church. ${ }^{198}$ In the short

\footnotetext{
192 Øie in Evensen et al., op. cit. (note 16), 64. 'Og så fikk vi selvfølgelig høre internt at vi var i lomma på helsemyndighetene, at vi var kjøpt og betalt, at vi hadde fått fine PC-er og fine skrivebord og reiste på dyre seminarer'.

193 Berridge, op. cit. (note 6), 20

${ }^{194}$ Pederstad interview, op. cit. (note 64). '[S]amtidig som man ikke skal kjøre hele homselivet i grøfta, med respekt for hva homsene hadde holdt på med. Og det er klart at det ikke er veldig lett å få respekt i samfunnet for pissoarkultur og Frognerparken og heller ikke nattelivet ute på byen. Det var ikke så mye seriøsitet å vise til.' [Frogner Park is a big public park in Oslo known for its cruising spots.]

195 Ibid.

196 Robertsen, op. cit. (note 178).

197 Quote by Tor Bjarne Bore in Dag Bjørndal, 'For sterk?', Klassekampen, 18 October 1986, 27.

${ }^{198}$ For instance, a prominent pastor declared that 'AIDS is God's punishment for a sinful life', which led to big
} 


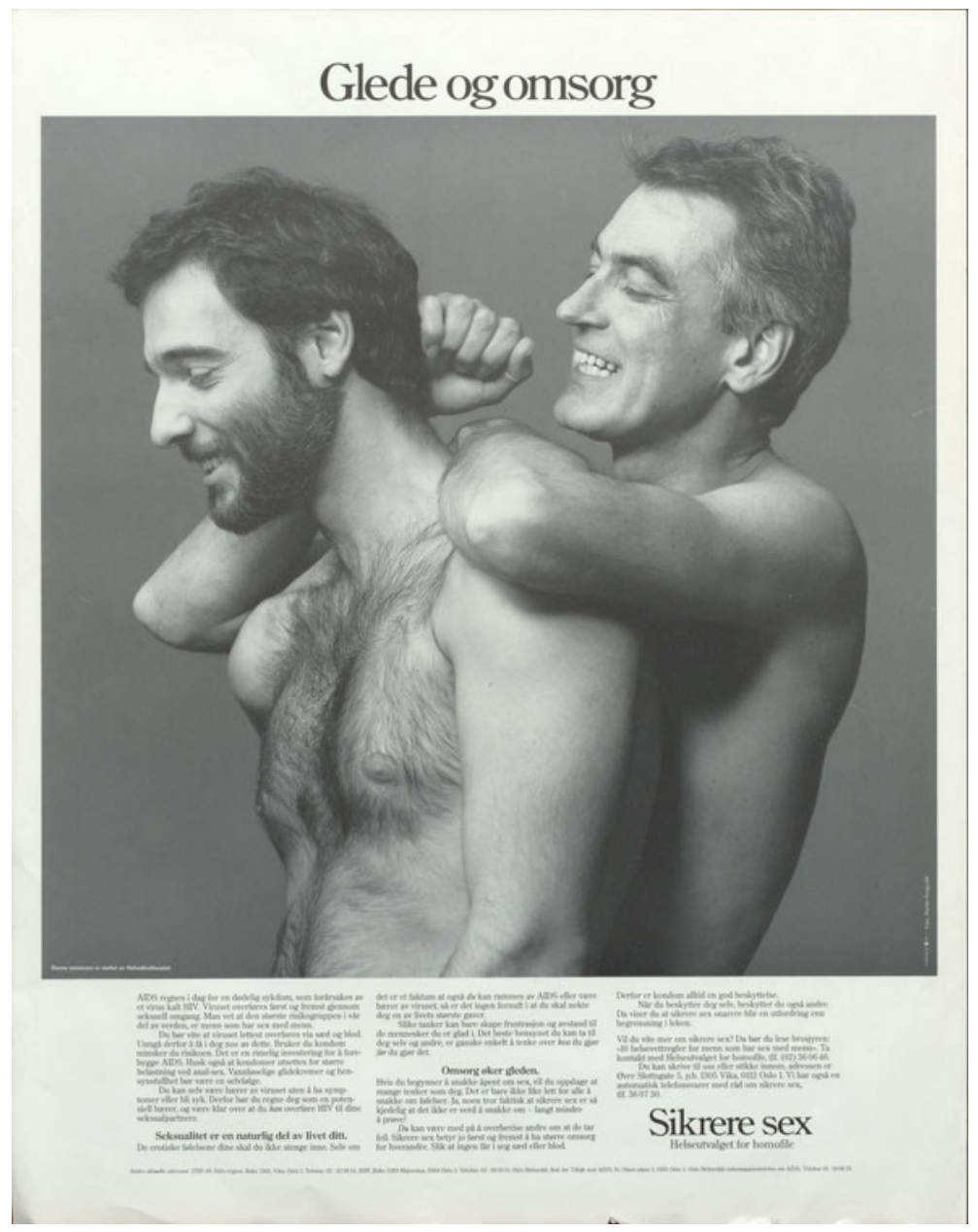

Figure 5: 1986 safer sex campaign by the Gay Health Committee, titled 'Pleasure and Care'. Skeivt arkiv, Bergen. Copyright: Helseutvalget.

run, AIDS complicated the coming-out process for many men and women and added to a stigma that was already widespread in society. ${ }^{199}$ 'AIDS has led to increase in gay bashing which also affect lesbians, even if lesbians as a group are not at risk of AIDS', the Gay Health Committee stated in the first working programme from $1986 .{ }^{200}$ It added that coming out for gays and lesbians had become harder and the struggle for rights and freedom was about to stagnate. On the other hand, AIDS made queer liberation much more visible, as activists got access to the press and to politicians in completely new

headlines in the newspapers without the Church distancing itself from the statement; '-AIDS er Guds straff', Dagbladet, 12 August 1985, front page; for an account of the Church's role in the epidemic, see also Aage Müller-Nilssen in Evensen et al., op. cit. (note 16).

199 See Anick Prieur, Kjarlighet mellom menn i aidsens tid (Oslo: Pax forlag, 1988). Prieur's study was based on interviews with sixty-four men who had sex with men. One man said that 'AIDS has brought new times. I feel like I have crawled back into the closet', 12.

${ }^{200}$ Gay Health Committee, op. cit. (note 150). 'Som en følge av AIDS ser vi tendenser til økende homo-hets. Denne homo-hetsen rammer også lesbiske, til tross for at lesbiske som gruppe, ikke er utsatt for å få AIDS.' 
ways. In the long run, this probably contributed to the normalisation and acceptance of sexual minorities in society. ${ }^{201}$ 'We didn't run back into the closets', an activist said in an interview, claiming that activists used the epidemic to talk about homosexuality and explain what it was. ${ }^{202}$

Nevertheless, being a gay man and AIDS activist was no guarantee that one did not reproduce exclusionary and patriarchal social hierarchies, even within the queer communities, by, for instance, neglecting the perspectives of lesbians or other minorities. ${ }^{203}$ The Norwegian population stayed fairly homogeneous until the 1960 s, then changed rapidly with an increase in work immigration from countries like Morocco, Turkey, Pakistan and Vietnam. ${ }^{204}$ At the advent of AIDS, Norway was no longer a homogeneous society, yet there were no efforts by activists or authorities to reach out to, or develop preventive policy directed at, different 'racial', ethnic or religious groups. Although AIDS brought gay men's agenda to the table, lesbians' health concerns were less urgent and became less prominent. For instance, the advisory service at the Health Council was started by gays and lesbians to serve the needs of the gay and lesbian communities, but when the special somatic health service for gay men opened in 1983, lesbian health was not included, and even if lesbians played an important role in founding the Gay Health Committee, its main objective was to prevent AIDS (among gay and bisexual men). It was important to DNF-48 that AIDS would not become associated with lesbian liberation, so the first information leaflet about AIDS, which addressed 'gay men', was only distributed to the organisation's 'male members' ${ }^{205}$ The Norwegian story of gay and lesbian AIDS activism is rather one of lesbians mobilising for and writing in solidarity for gay men than gay men including lesbian health in a broad concept of gay and lesbian health. 'The risk of AIDS has created much awareness of gay men's health', a doctor and lesbian activist wrote in the Journal of the Norwegian Medical Association in 1986. ${ }^{206}$ Even if there were few 'specific lesbian health problems', doctors had to be aware of lesbians' needs and not assume that all female patients were heterosexual, she argued. At the same time, lesbian activists called for lesbians to show solidarity with gay men in the AIDS crisis, arguing that 'there is a big risk that the AIDS epidemic will lead lesbians to become even more invisible and that lesbians' demands will be given even less priority'. ${ }^{207}$ Another lesbian activist wrote in Løvetann that 'in Norway until now, lesbians have not been particularly visible', referring to AIDS activism, and contrasted this with the situation in the US. ${ }^{208}$ She argued that if solidarity with gay men in AIDS activism meant that all other gay and lesbian political work was neglected, she could

\footnotetext{
${ }^{201}$ Many scholars have made this argument. For one of the earliest, see Dennis Altman, 'Legitimation through disaster: AIDS and the gay movement', in Fee and Fox, op. cit. (note 15), 301-15.

202 Åse interview, op. cit. (note 103).

203 The perspective and role of bisexual and transgender people have often been neglected in the historiography of AIDS activism. Unfortunately, I have not managed to identify any references to bisexual or trans activism in the archives I have consulted.

${ }^{204}$ For Norwegian immigration history, see Grete Brochmann and Knut Kjeldstadli, A History of Immigration: The Case of Norway 900-2000 (Oslo: Universitetsforlaget, 2008).

${ }^{205}$ Kim Friele to the Directorate of Health, 4 March 1983, AIDS folder, NAN.

206 Kirsti Malterud, 'Helseforhold hos lesbiske kvinner', Tidsskriftet for Den norske lageforening, 25, 106 (1986), 2071-4.

207 Turid Eikvam and Marit Skogstad, 'AIDS og lesbiske', Løvetann, 4 (1987), 46-7, SA. 'Det er stor fare for at AIDS-epidemien fører til at lesbiske blir ytterligere usynliggjort og at særegne lesbiske krav blir nedprioritert.'

${ }^{208}$ Karin Enderud, 'Angår AIDS lesbiske?', speech at the national conference on AIDS, Løvetann, 3 (1986), 33, SA. 'I Norge har ikke lesbiske vært synlig aktive hittil.'
} 
understand the lack of engagement: 'We must not let AIDS work drain the gay and lesbian organisations for time, strength, and money while lesbians again are neglected in gay and lesbian liberation.' 209 The lack of interest in lesbian health or lesbian liberation more broadly was not a particular Norwegian phenomenon. It was also reported in neighbouring countries, for instance, as a specific topic at a Scandinavian AIDS activism conference in 1987. However, some gay men did raise the topic of lesbian health being neglected. 'Generally, health is important and in particular among lesbians, because I think lesbian women have health issues', Almedal wrote in a review of two books on lesbian health. 'I think that they [the books] are important for gay men too. The better we get to know each other, the easier it will be to live, work and be together.' ${ }^{210}$ Sometimes, the increased public funding AIDS brought with it spun off in ways that benefited sexual minorities more generally. A lesbian activist and psychologist at the counselling service recalled in an interview how the government's willingness to fund AIDS preventive measures and empower sexual minorities enabled her to secure public funding for a course targeted at lesbians on how to 'date and hit on women'. ${ }^{211}$ Ultimately, the Gay Health Committee did put lesbian health on the agenda, culminating in a conference in September 1988 for lesbians from around the country and organisations from Sweden and Denmark. In an article titled 'Lesbians on the offensive', the author reported that part of the programme included "collective training of "the orgasmic musculature", and the participants were encouraged to adopt the motto 'dissolve the nuclear family'. 212

\section{Conclusion}

AIDS appeared in Norway in the midst of a restructuring of the public healthcare system, and the reforms of the 1970s and 1980s sought to deprofessionalise and decentralise the health bureaucracy. By removing physicians from positions in the medico-political system, politicians wanted to separate medicine from politics. However, AIDS demonstrated the inseparability of the two: medicine is politics. This chapter of history shows that the professionalised, physician-dominated system had not disappeared in practice even if it had on paper. As Virginia Berridge wrote about the UK, AIDS 'stressed the essential continuity of policy-making traditions through a period of apparent conservative revolution'. ${ }^{213}$ Norway did not go through a similar 'conservative revolution', as parties on both sides of the ideological spectrum agreed on the main objectives of healthcare policy. In Norway, AIDS mobilised old structures in the postwar system of social medicine: the Directorate of Health and Oslo Health Council. The directorate lost its powerful position the same year as the first cases of AIDS were reported, and Oslo Health Council was dissolved in 1988, in the midst of the epidemic. Nevertheless, it was in and through these two bastions of social medicine that much of the official AIDS response was hammered out. This response was rooted in the thought style of social medicine with its tradition of integrating sexual health in a broad concept of health. However, AIDS reshaped social medicine too, as AIDS activists challenged paternalistic, heteronormative and homophobic

\footnotetext{
${ }^{209}$ Ibid., 33 'Vi må ikke la AIDS-arbeidet tappe de homofile organisasjonene for tid, krefter og penger, samtidig som lesbiske igjen blir underprioritert i det homofile frigjøringsarbeidet.'

${ }^{210}$ Calle Almedal, 'Lesbisk helse spiller en rolle', Lovetann, 1 (1985), 51. 'Helse generelt sett er viktig og helse blant lesbiske spesielt, fordi jeg tror at lesbiske har helseproblemer. .. . [J]eg mener også at de er viktige for alle homser. Jo mer vi lærer hverandre å kjenne, desto lettere blir det å leve, arbeide og være sammen.'

211 Anbjørg Ohnstad, interview with author, Oslo, 16 May 2019.

${ }^{212}$ Kirsten Frigstad, 'Lesbiske på offensiven', Lфvetann, 5/6 (1988), 52.

213 Berridge, op. cit. (note 6), 8.
} 
tendencies in the healthcare system and thinking of social medicine. AIDS represented a completely new challenge to the healthcare system and public health policy, which created a climate for tinkering and experimenting with new ways of thinking and doing social medicine, empowering stigmatised groups and cooperating with and involving those prone to infection in that work.

AIDS activists and, in particular, gay and lesbian health activists managed to get a seat at the table, thereby gaining visibility and recognition. By mobilising activists, the government also secured credibility for their policy. Being gay or lesbian and a medical professional put activists in a unique position from which they could access the gay and lesbian communities and also address pressing health issues. As members of the community, they had easy access to spaces where gay men met, including bars, restaurants and bathhouses, and thus had first-hand experience and information about the community they sought to protect. This proved invaluable for hammering out health strategies with the health authorities. Some of these gay men had themselves enjoyed the possibilities the increased sexual freedom had given them. They had participated in a lifestyle filled with sex and drugs at the same time as they had witnessed the devastating consequences of AIDS. Therefore, they argued that this had to change. 'They saw how dangerous it was, they had a lot of friends in the US who became severely ill and died, and they went to numerous funerals', a physician and AIDS activist said. 'Therefore, they thought that very strong measures were needed, even moralistic ones. ${ }^{, 214}$ This article has argued that it was this amphibious role of being gay or lesbian and a medical professional, of having experienced sexual liberation and the horrors of AIDS, which gave them credibility among gay men and the authorities. This role enabled a position from which even moralistic measures could be defended. For the authorities, lacking these experiences and credibility, it would have been impossible to create the same prevention and information work, at least with a similar impact.

One AIDS and drug policy activist remembered that he was invited to a conference in Sweden with the health director's AIDS team because the hosts sought to have 'both sides' represented, gay activists and officials. Representing the activists, he ended up never giving his speech because, as he recalled, 'there was no disagreement, we compared our speeches. ... There was no reason to give the same speech twice'. ${ }^{215}$ To him this was 'a symbolic act that showed that the Norwegian gay and lesbian movement and the authorities stood shoulder to shoulder'. ${ }^{216}$ However, as I have argued in this article, the picture was more complex. In the early phase of the epidemic, activists mobilised mostly without government support. Gay and lesbian healthcare workers and activists were moved to act out of care for their patients and their communities. From the middle of the decade, the authorities started cooperating with AIDS activists more closely, for instance, by funding their work. The amphibious nature of AIDS activism often meant negotiating insecurity and juggling conflicting roles in order to avoid jeopardising credibility. This story demonstrates how important but challenging it was for activists to work with the government and as healthcare workers while trying to retain trust in the gay and lesbian communities.

${ }^{214}$ Iversen interview, op. cit. (note 167). '[D]e så at det var kjempefarlig, de hadde masse venner i USA som ble alvorlig syke og døde, de gikk jo i mange begravelser. Og de mente da at da måtte man ta i bruk veldig sterke virkemidler, også moralistiske'.

215 Blindheim interview, op. cit. (note 181). 'Vi var jo helt enige om alt, vi sammenliknet foredrag. ... Det var ingen grunn til å holde to foredrag'.

216 Ibid., ‘. . . det var en symbolhandling på at myndighetene og i hvert fall homolobbyen sto skulder ved skulder i Norge.' 